\title{
HONEY LAKE HYBRID GEOTHERMAL WOOD RESIDUE POWER PLANT \\ Lassen County, California
}

\section{Project Feasibility Summary Report}

\section{Sponsors:}

GeoProducts Corporation USDA Forest Service

California Department of Water Resources

U.S. Department of Energy

June 1982 


\section{DISCLAIMER}

This report was prepared as an account of work sponsored by an agency of the United States Government. Neither the United States Government nor any agency Thereof, nor any of their employees, makes any warranty, express or implied, or assumes any legal liability or responsibility for the accuracy, completeness, or usefulness of any information, apparatus, product, or process disclosed, or represents that its use would not infringe privately owned rights. Reference herein to any specific commercial product, process, or service by trade name, trademark, manufacturer, or otherwise does not necessarily constitute or imply its endorsement, recommendation, or favoring by the United States Government or any agency thereof. The views and opinions of authors expressed herein do not necessarily state or reflect those of the United States Government or any agency thereof. 


\section{DISCLAIMER}

Portions of this document may be illegible in electronic image products. Images are produced from the best available original document. 
This report was prepared with the partial support of the U.S. Department of Energy; Grant No. DE-FG03-79ET27244. However, any opinions, findings, conclusions, or recommendations expressed herein are those of the author(s) and do not necessarily reflect the views of DOE.

\section{DISCLAIMER}

This report was prepared as an account of work sponsored by an agency of the United States Government. Neither the United States Government nor any agency thereof, nor any of their employees, makes any warranty, express or implied, or assumes any legal liability or responsibility for the accuracy, completeness, or usefulness of any information, apparatus, product, or process disclosed, or represents that its use would not infringe privately owned rights. Reference herein to any specific commercial product, process, or service by trade name, trademark, manufacturer, or otherwise does not necessarily constitute or imply its endorsement, recommendation, or favoring by the United States Government or any agency thereof. The views and opinions of authors expressed herein do not necessarily state or reflect those of the United States Government or any agency thereof. 
FOREWORD

This volume is a summary of an ambitious 3-year feasibility evaluation of the proposed Honey Lake Hybrid Geothermal-Wood Residue Electric Power Project near Susanville, California. The evaluation has been sponsored jointly by GeoProducts Corporation, the U.S. Department of Agriculture-Forest Service, the California Department of Water Resources, and the U.S. Department of Energy.* The project is a first attempt on a commercial scale to use wood fuel and geothermal resources together for electric power production.

The Summary which follows highlights research and conclusions in four areas crucial to the successful continued development of the project: geothermal resource development; wood fuel supply, engineering and economic factors, and pertinent environmental issues. The principal contractors associated with the respective research areas are identified. Their assistance in the completion of the project feasibility evaluation together with that of many other agencies, companies, and individuals is gratefully acknowledged.

The San Francisco Operations Office of the Department of Energy administered a Geothermal Energy Research and Development Grant in partial support of the Feasibility Study; the Idaho Operations office administered cost-shared support for the drilling operations under DOE's User-Coupled Confirmation Drilling Program. 
TABLE OF CONTENTS

FOREWORD

Page No.

1.0 Executive Summary 1

1.1 Project Description and Conclusions 1

1.2 Geothermal Resource Development 3

1.3 Wood Fuel Supply and Cost Analysis 4

1.4 Engineering and Economic Analysis 5

1.5 Environmental Issues Assessment 7

2.0 Geothermal Resource Development 9

2.1 Siting of Exploratory Well WEN-1 9

2.2 Drilling Summary 11

2.3 Revised Geothermal System Model 15

2.4 Flow Test Results 17

3.0 Wood Fuel Supply and Cost Analysis 21

3.1 Wood Fuel Availability 2.1

3.2 Wood Fuel Properties 25

3.3 Fuel Harvesting Methods 30

3.4 Procurement Strategy 31

3.5 Wood Fuel Costs 34

3.6 Procurement Organization 36

3.7 Constraints and Benefits 36

4.0 Engineering and Economic Analysis 39

4.1 Combustion Optimization 39

4.2 Plant Capacity Analysis... 40

4.3 Wood Fuel Handling System 41

4.4 Plant Cycle Optimization 41

4.5 Wood Fuel Drying 45

4.6 Emission Controls 46

4.7 Ash Handling and Plant Cooling 49

4.8 Performance Gains Using Geothermal Energy 50

4.9 Economic Analysis 52

5.0 Environmental Issues Assessment $\quad 55$

5.1 State Certification $\quad 55$

5.2 Air Quality Maintenance 56

5.3 Other Environmental Issues 57

5.4 Design of Mitigation Measures 61 
Table of Contents - Cont'd

Page No.

6.0 Implementation Recommendations

62

$\begin{array}{lll}7.0 & \text { Related Studies } & 64\end{array}$

7.1 Combined Cycle Plant Design 64

7.2 Comparative Power Cost Analyses 68

\section{FIGURES}

1-1 Project Location 2

2-1 Geoproducts Leasehold Boundary and 10 Recommended Drill Sites

2-2 Drilling Time Profile 12

2-3 Lithology Column 14

2-4 Well Construction Profile 16

2-5 Flow Testing Assembly 19

3-1 Fuel Procurement Area 23

4-1 Fuel Handling System 42

4-2 Plant Cycle and Heat Balance Diagram 44

4-3 Rotary Dryer 47

7-1 Combined Cycle Plant Schematic Diagram 66 


\section{TABLES}

Page No.

3-1 Land Ownership

3-2 Biomass Fuel Properties for Wood Species Common to the Susanville Procurement Area

3-3 Wood Fuel Heating Values by Procurement Area Supply Category

3-4 Daily Consumption and Form of Wood Fuel Materials

3-5 Estimated cost of Fuel by Source and Location

3-6 Projected Cost of Fuel

4-1 Performance Variations with Geothermal Wood Drying

4-2 Performance Gains From Economically

Feasible Geothermal Applications

4-3 Plant Investment and Costs

4-4 Rates of Return

5-1 Estimated Direct Employment

7-1 First Year Operating Expenses and cost of Power 


\subsection{EXECUTIVE SUMMARY}

\subsection{Project Description and Conclusions}

The subject of the feasibility evaluation is a proposed 50 MW (gross) electric power project located near Wendel, California about 25 miles east of susanville (See Fig. 1-1). The project would be the first commercial power plant to combine the use of geothermal energy and wood fuel for power production. Wood fuel consisting primarily of various forms of forest management residues would be processed and partially dehydrated with geothermal energy prior to combustion. Geothermal energy would also be used for boiler feedwater heating and combustion air preheating. Most of the electricity would be used by the state of California to help meet the electric power needs of the State Water Resources Development System, and to do so consistent with the State's emphasis on the use of renewable resources for power generation. Up to a third of the plant electric power output would be available to help meet local power needs. Geoproducts Corporation would be the plant owner and operator. Participation in the project by the U.S. Forest Service is to study and encourage beneficial effects to forestlands of this and similar projects through removal and use of various forms of forest management residue.

A principal objective of the feasibility study was to define the range of site-specific benefits and economics of using wood fuel and moderate temperature geothermal energy, both of which are abundant and often located in proximity at many locations in the western United states. The study results document conclusively that overall project economics can be very favorable 


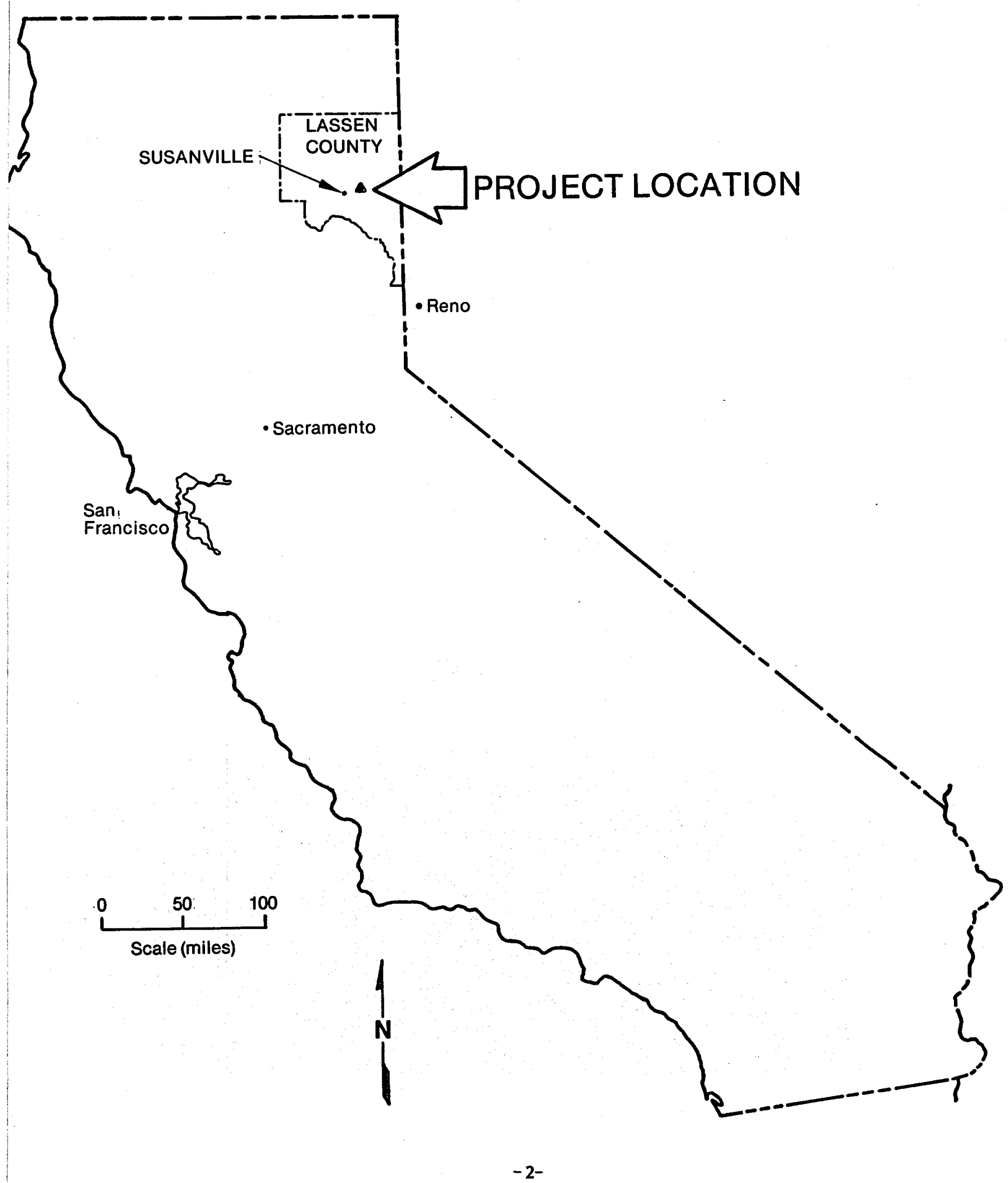


and that in addition to providing an important source of electric power, many benefits to forest land managers, local communities, project developers and the state of the environment can be derived from the combined use of moderate temperature geothermal energy and wood fuel.

1.2 Geothermal Resource Development

Field exploration activities initiated by Geoproducts Corporation in 1977 culminated in the successful completion of a deep production well in september 1981. The well was drilled to a depth of 5,823 feet (surface measurement) and completed in a fractured, largely granodiorite formation. A broad fault zone with associated fractures occurs at approximately 5,300-5, 350 feet and serves as the main production zone. Well testing to date suggests a highly productive well (about $20 \mathrm{gpm}$ per psi capacity) with no immediate boundaries. Long term testing was conducted at a constant artesian flow rate of $670 \mathrm{gpm}$. Pressure recovery from testing was very rapid, indicating a highly transmissive producing zone. A minimum reservoir temperature of $251^{\circ} \mathrm{F}$ was measured at 5,200 feet during flow testing.

Water sampling conducted to date indicates the well fluid is a $\mathrm{Na}-\mathrm{SO}_{2}-\mathrm{Cl}$ water relatively high in boron, fluoride, and silica. Silica enthalpy and chloride enthalpy diagrams suggest that the well fluid originates from a reservoir whose temperature is in the $275-310^{\circ} \mathrm{F}$ range.*

*Based on an analysis of the well fluid conducted by the Earth Science Laboratory, University of Utah Research Institute. 
The drill site selected for deep exploration was one of three identified in the geothermal resource feasibility study. This study synthesized all previous geologic, geophysical, and hydrologic research on the Honey Lake prospect. The study also hypothesized the existence of a widespread fractured volcanic reservoir underlying the Wendel-Amedee area. The data obtained from the deep exploration well, analyzed in conjunction with data from two other deep wells drilled on the prospect by Gulf oil Company suggests that the geothermal system is largely confined to fractured zones associated with specific faults and that geothermal aquifers associated with extensive volcanic formations are probably of limited extent.

other sites on the leasehold, including the remaining two sites identified in the feasibility study, are being studied for future deep drilling efforts.

1.3 Wood Fuel Supply and Cost Analysis

A wood fuel supply study was conducted based on an assumed fuel requirement of 1000 oven dried (OD) tons per day although it is expected that the 50 MW plant would actually require about 730 oD tons daily.

Seven general wood fuel supply categories were identified in a procurement area of some 15 million acres of predominately public-owned lands within an approximate 100-mile radius of the project area. The most substantive of these supply categories, and the one from which it is expected that most of the wood fuel will be obtained is logging slash and dead-and-down trees. Slash removal will provide several benefits to forest land managers including greater insect and disease control, intensified forest management, and cost 
savings related to slash collection and burning (estimated to be about $\$ 125$ per acre). Obviating the need for slash burning will also improve local air quality.

The availability of wood fuel to the project is assured in each of the four decades for which projections were made. During the 1980-89 decade, fuel supplies will be the most constrained, but even during this period the maximum fuel requirement for the project is only about one-third of the economically available supply. In succeeding decades, the surpluses are even more substantial. The projected surpluses are significantly greater than the norms frequently used by the pulp and paper industry to support investment decisions many times the size of the investment level in the Honey Lake Hybrid Power project.

The estimated average cost of wood fuel to the power plant during the 1980-89 decade, based on prevailing equipment, fuel, and labor rates in 1980 , is $\$ 25.30$ per OD ton. In subsequent decades the project can expect a substantial reduction, in the range of 15-20 percent in 1980 values, in the cost of fuel.

\subsection{Engineering and Economic Evaluation}

The engineering design is based on the drying of wood fuel prior to its combustion in a conventional steam cycle generating $50 \mathrm{Mw}$ of gross electric output. Geothermal source temperatures of 225,275 , and $340 . \mathrm{F}$ were used to derive equipment specifications, capital expenditures, and operating costs. The use of geothermal fluids for boiler feedwater and combustion air heating was also studied and found to contribute 
substantially to the viability of the project. Wood fuel characteristics of 50.8 percent moisture content and 4,502 Btu per pound, as determined in the wood fuel study, were used for design bases.

Rotary system drying and stoker firing of the wood fuel offers capital, operating, and maintenance cost advantages over other drying and combustion systems studied.

Capital expenditures, fuel savings, and annual costs vary significantly according to the extent of geothermal energy use in fuel dehydration and feedwater and combustion air preheating. Rates of return were calculated in lowering the moisture content from 50.8 percent to, in turn, 45, 30, and 15 percent. Using geothermal fluid at 275 or $340 \cdot \mathrm{F}$, fuel drying to 45 percent moisture content is the economic optimum. No fuel drying is economically feasible at a geothermal source temperature of $225^{\circ} \mathrm{F}$. Rates of return are also highly dependent on the efficiency of geothermal energy use in combustion air and boiler feedwater heating. At a source temperature of $275^{\circ} \mathrm{F}$, for example, fuel savings of about 4 percent are realized with feedwater heating and about 6 percent savings are obtained when combustion air is preheated. If all three modes of geothermal use are incorporated into the plant, a total fuel savings of about 14 percent is achieved.

Total investment for a plant using $275^{\circ} \mathrm{F}$ geothermal water is estimated to be $\$ 87,544,000$ (1985 value, construction interest not included). Project rates of return are about 22 percent for 100 percent equity financing. Rates of return vary in the range 35-43 percent on 75 percent debt financing at interest rates 
of 8-14 percent with an estimated first year cost of power of $79.18 \mathrm{mills} / \mathrm{kwh}$ (see page 70 ).

1.5 Environmental Issues Assessment

Particulate and gaseous emissions from wood combustion, while less troublesome than in other types of plants, need to be considered in selection of plant components. since wood and bark are essentially sulfur-free, low in nitrogen, and require a lower air/fuel ratio for stochiometric combustion, exhaust gases are essentially free of $\mathrm{NO}_{\mathrm{X}}$ and $\mathrm{SO}_{\mathrm{X}}$. The only appreciable gaseous pollutant from wood combustion is carbon monoxide. Flue gas particulate emissions can be minimized by the use of commercially available staged air pollution control equipment.

No rare or endangered plant or animal species are resident in the project area, although bald eagles have been seen transiting the area.

Fresh water requirements of the project will require careful planning because of the demands placed upon shallow groundwater resources. To the extent possible, plant water requirements should be met with discharged geothermal fluids.

Wood ash will be the principal solid waste, with up to 20 tons per day requiring disposal. Final disposition of the ash will follow extensive combustion testing with the main concern being salt content and the potential for groundwater pollution. Land-fill burial or commercial use as fertilizer are the major disposal options. 
Liquid waste streams may be injected into deep wells or, pending final determination of the composite geothermal fluid quality, may be discharged benefi cially to one or both of the wildfowl management areas in the project vicinity.

Engineering characteristics of site soils, the possibility of ground surface subsidence from deep pumping, and the possible release of fuel-derived air emissions need further study.

The employment and financial benefits of the project to Lassen County and Susanville, where the present unemployment rate is about 25 percent, will be substantial.

Potentially adverse effects of the project include increased truck traffic through susanville and accelerated deterioration of some roads due to increased heavy traffic. A major area of public concern is the potential competition placed by the project on resources for home firewood. While the technical evaluation demonstrates that this concern is unfounded, the perception is nevertheless widespread. 
Interest in and exploration for geothermal resources in the northern Honey Lake Basin has been undertaken by various government agencies and private companies since the early 1960 's. An exploration program was begun by Geoproducts in 1977 with reconnaissance geophysical surveys over large sections of the leasehold. By 1980 the geophysical program, which included gravity, ground magnetic, scalor and tensor magnetotellurics, DC resistivity and time domain electromagnetic methods, along with four temperature gradient holes (479-1,325 ft.) had been completed in the area of the leasehold north and west of the Wendel Hot springs.

A synthesis of all available data related to the wendelAmedee geothermal area was reviewed and interpreted.* This report contains extensive surface and subsurface geologic, hydraulic, geochemical and geophysical data and interpretations, and includes the formulation of a basin model and the recommendation of three alternative sites for an initial exploratory hole.

2.1 Siting of Exploratory Well WEN-1 The three recommended drill sites, identified as WEN-W, WEN-E and $A M$ are shown on Fig. 2-1 with the extent of the Geoproducts leasehold. These sites were picked based on a geologic model which presumed a thick fractured volcanic section several thousand feet thick serving as the geothermal reservoir. This model was constructed largely from data (percentage lithologic logs) from Gulf oil company's two deep holes, ST-1 and ST-2, in the area. Fault dips were unknown or highly speculative.

* "Siting and Drilling Recommendations for a Geothermal Exploration Well, Wendel-Amedee KGRA, Lassen County, California," GeothermEx Inc., Berkeley, CA, December 1980. 


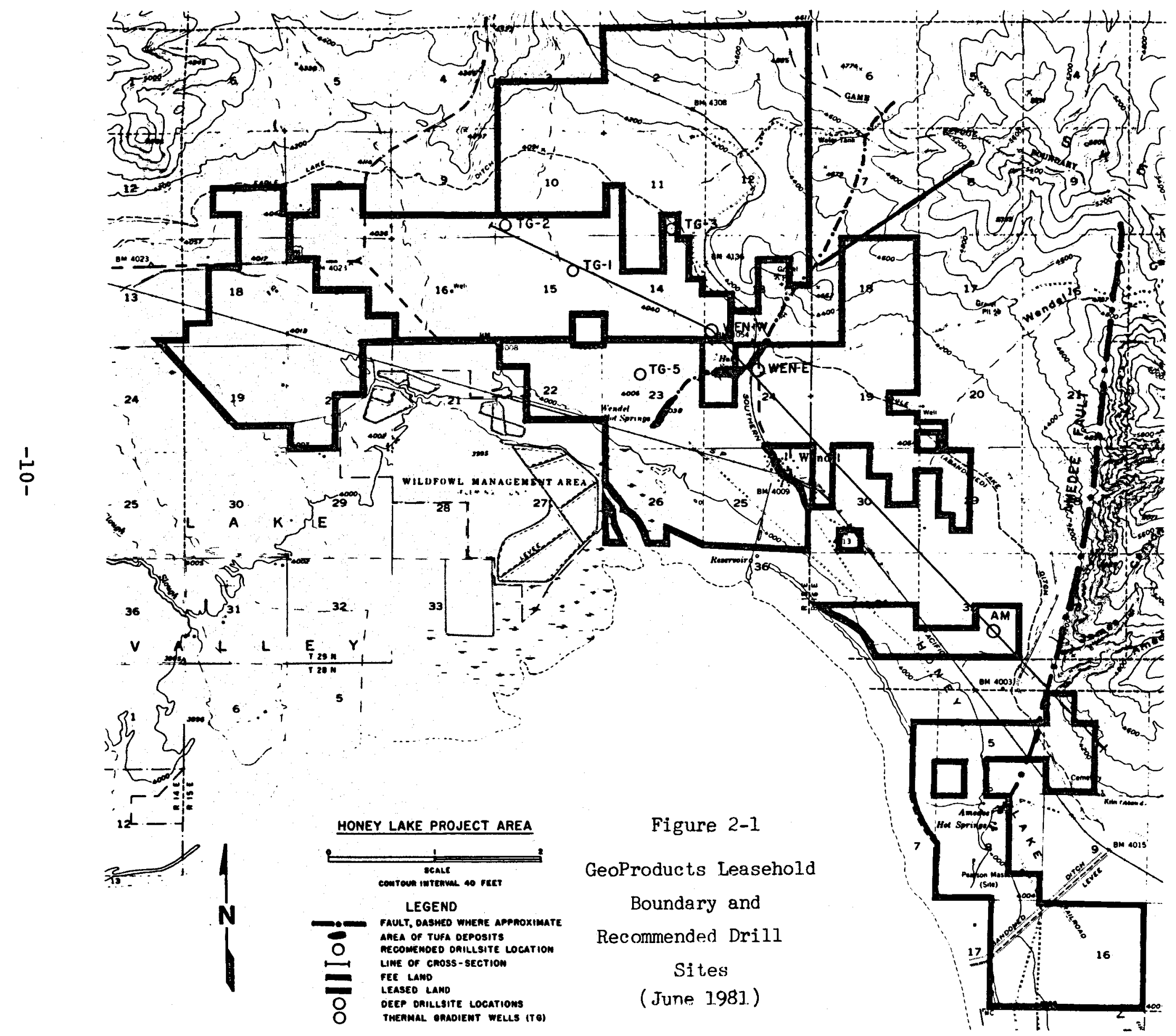


Subsurface formation characteristics, inferred from circulation losses during the drilling of the Gulf wells, and bedrock exposures as observed in the field by Geoproducts' geologists implied a greater extent of fracturing and hence potential permeability near the Wendel sites. The Wendel site was also located within an area where several mapped bedrock lineations as well as several postulated faults converged. A stronger geophysical data base near Wendel was also a consideration in selecting a site in that area.

The final site selection at $W E N-W^{*}$ was made on the basis of reconnaissance geologic mapping and photogeologic interpretations which indicated a north striking structure dipping $60^{\circ}-70^{\circ}$ northwest. This structure can be traced from the linear tufa mounds at the Wendel Hot Springs for at least 2.5 miles north through the western skedaddle Mountains. The drill site was offset from this structure in order to encounter the fault or fault zone at approximately 5,000 feet. Three broad targets were considered: a fractured volcanic reservoir between 3,000 and 5,000 feet, the Wendel Fault zone near 5,000 feet in either volcanic or granitic rock, or a fractured granite (basement) reservoir below 5,000 feet possibly in the footwall of the Wendel Fault.

\subsection{Drilling Summary}

The well was spudded on August 1,1981 and proceeded for the next 51 days, to september 22 , according to the drilling time profile shown in Fig. 2-2. Troublesome

*For ease of permitting, site WEN-W identified in the GeothermEx Report, was changed to WEN-1; and will be so referenced hereafter. 


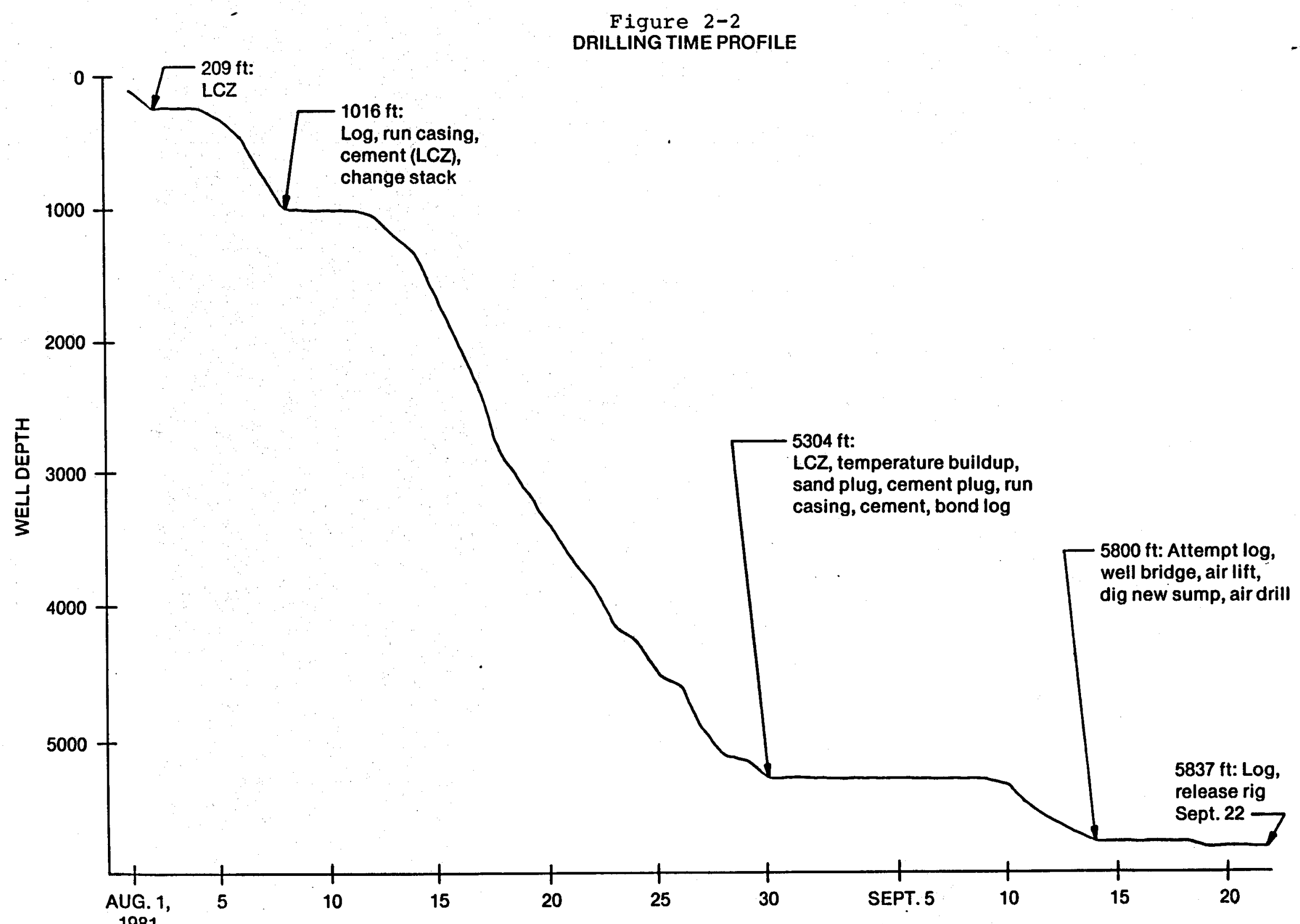


lost circulation zones were encountered at 209, 1,016 and 5,304 feet.* At the latter two depths casing strings were run, and at 5,304 feet a sand plug was set to protect what was believed to be a producing interval. The well was drilled to a total depth (TD) of 5,837 feet, encountering the formations shown in Fig. 2-3. Well logs were run as follows:

1,016 feet: Dual Induction-Laterlog with spontaneous potential, temperature log.

-5,304 feet: Dual Induction-Laterlog with spontaneous potential, compensated neutron/density log with gamma ray and caliper, borehole compensated sonic with gamma ray, caliper and seismic spectrum, temperature log (2).

-5,837 feet: Dual Induction-Laterlog with spontaneous potential, temperature(2), borehole compensated sonic with caliper, gamma ray and seismic spectrum.

The main production zone is in the granodiorite and extends from about 5,300 to 5,350 feet.

Water sampling conducted to date indicates the well fluid is a $\mathrm{Na}-\mathrm{SO}_{2}-\mathrm{Cl}$ water relatively high in fluoride, boron, and silica. Silica enthalpy and chloride enthalpy mixing/geothermometer diagrams suggest that the well fluid emanates from a reservoir whose temperature is in the $275-310^{\circ} \mathrm{F}$ range.

The well casing profile is as follows (surface measurement):

* All measurements unless otherwise noted, are from Kelly Bushing which was $14 \mathrm{ft}$. above ground level. 


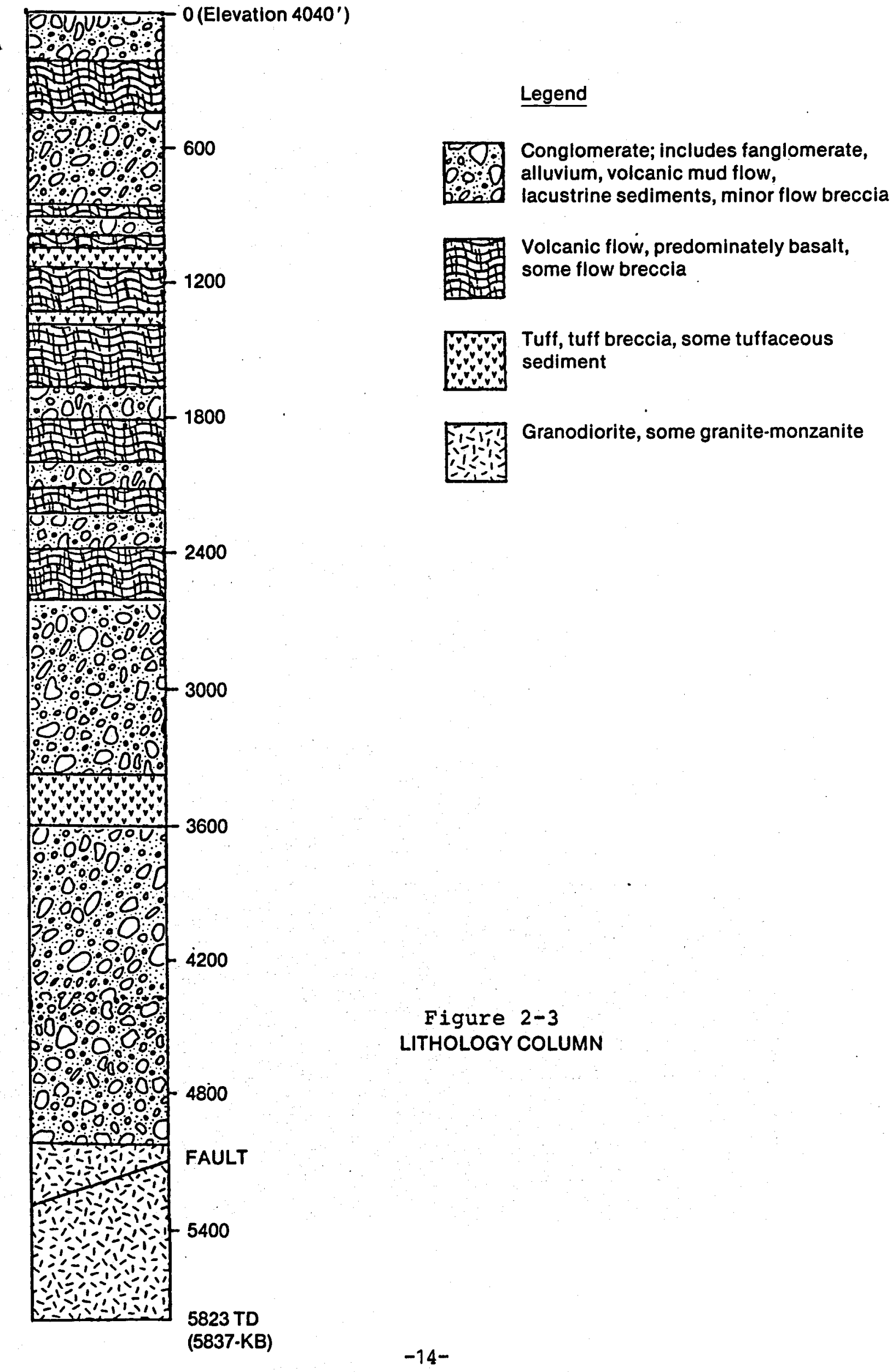




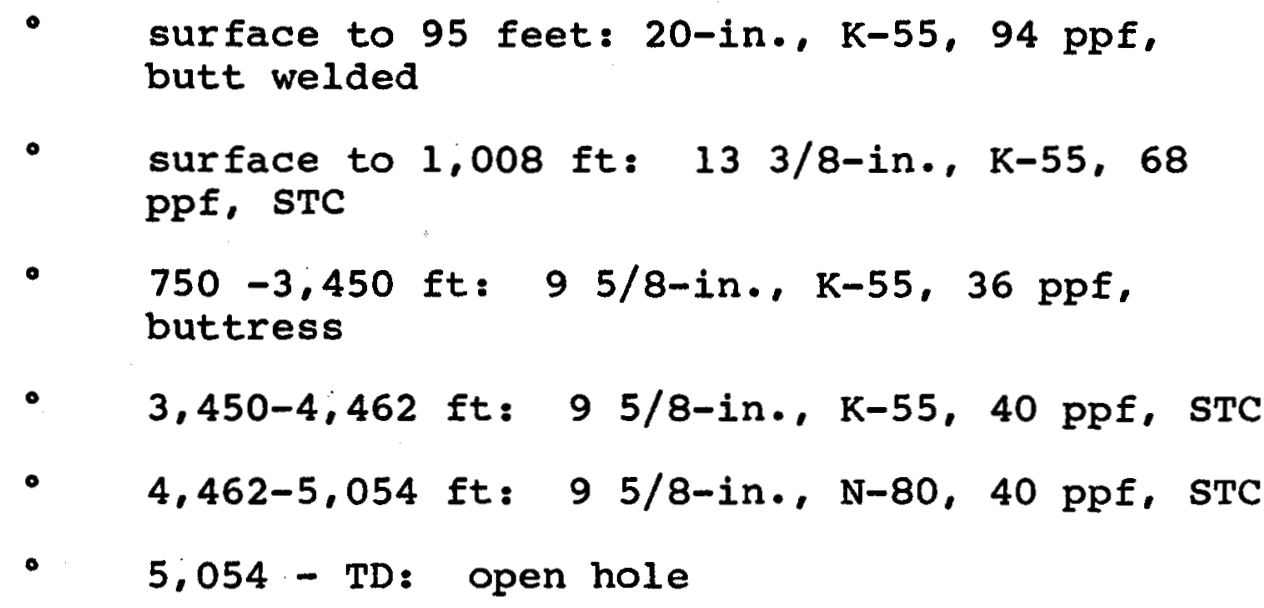

Wel1 testing conducted in November 1981 revealed that the casing had cracked or separated, at which time testing operations were terminated. A televiewer run in the well confirmed a crack in the joint between 211-251 feet. Repair operations on the well were undertaken with a workover rig from February 13-18, 1982. The casing crack, which proved to be at 236 feet, was sealed with cement, and a $103 / 4-i n$. Iiner (J-55, 40.5 ppf, STC) run back from the overlap of the 9 5/8-in. and the $133 / 8-i n$. casing at 750 feet to 186 feet. (See Fig 2.4). The repair operation was completely successful and the well restored to full productivity.

\subsection{Revised Geothermal System Model}

The data obtained from WEN-1; analyzed in conjunction with the cuttings and well logs from the two Gulf wells, has provided increased understanding of the thermal system and subsurface geology in the northeastern Honey Lake Basin. Additionally, an ongoing exploration program which includes regional water sampling (major and trace chemistry, stable isotopes), soil geochemistry, geologic mapping and the acquisition of more recent and extensive geophysical data is continually refining the system model. 


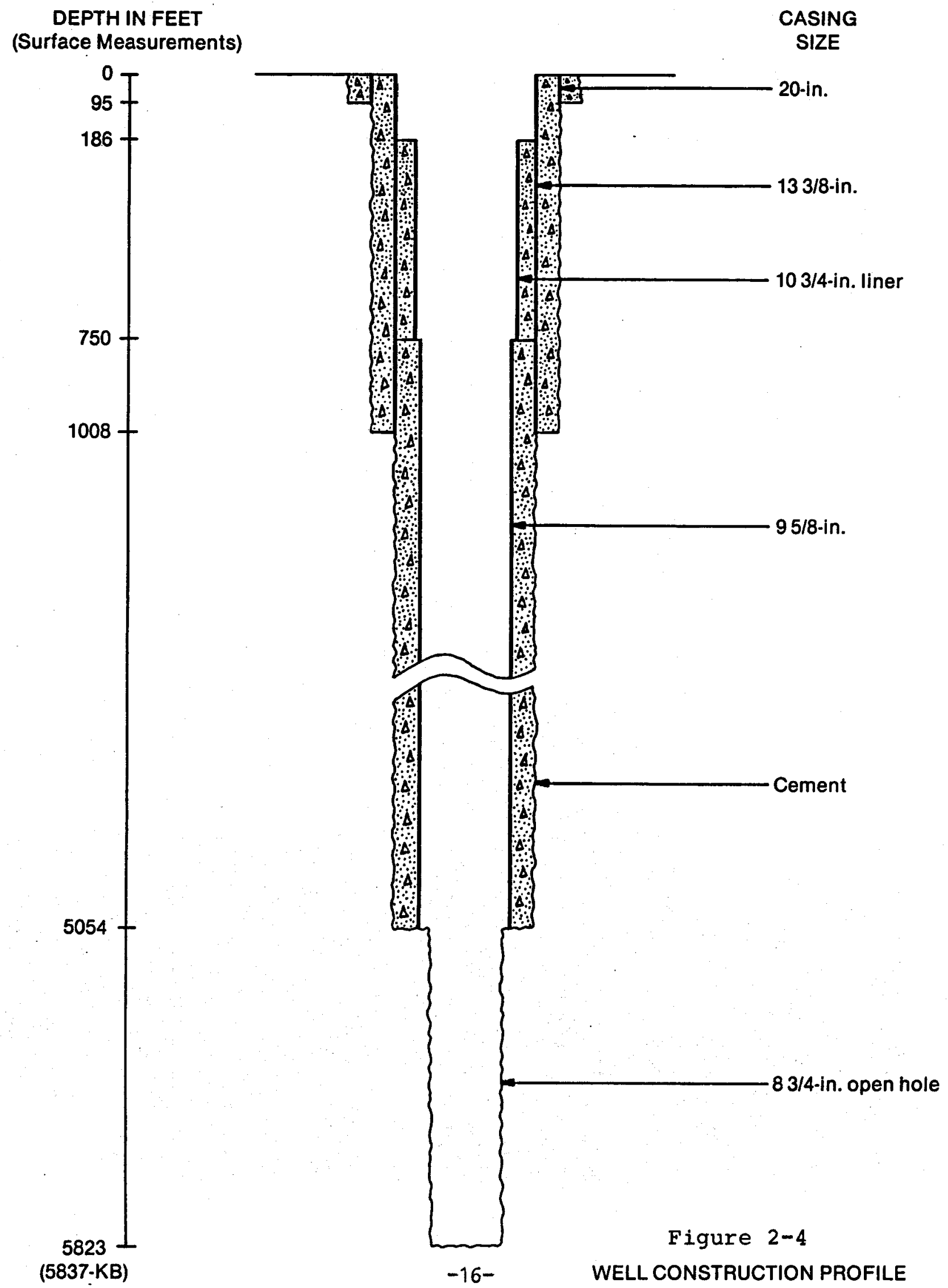


The present conceptual model of the thermal system precludes the presence of a widespread fractured volcanic rock reservoir underlying the Wendel-Amedee area. It appears that the system is largely confined to fractured zones associated with specific faults and that volcanic aquifers are probably of limited extent.

In WEN-1 volcanic rocks were penetrated from 300 feet to approximately 4,550 feet variously interspersed with sections of sediments, largely coarse grained conglomerates. In the section from 2,600 feet to 4,550 feet the materials penetrated were devoid of volcanic flows but were comprised of highly altered tuff, tuffaceous sediment; mudflow; and conglomerate of uncertain (probably epiclastic) origin. These later lithologic types were very clay rich and showed little or no permeability. From 4,550 to the top of the granitic basement at 5,050 feet a conglomerate of clearly distinct character, with somewhat less clay component was penetrated and showed no permeability. From $5050 \mathrm{ft}$. to total depth "Sierran," largely granodioritic variously fractured rock was encountered. A broad fault zone with associated fractures occurs at approximately 5300-5350 ft. and serves as the main production zone.

An important feature of the lithologic log (Fig. 2-3) is the thick section of conglomerate below 2,600 feet nearly all of which exhibited very poor characteristics as potential reservoir material.

\subsection{Flow Test Results}

The flow testing of WEN-1 began March 1, 1982. The test format called for initial temperature, pressure, and spinner surveys to TD followed by a series of 
constant flow/recovery tests at varying rates and durations.

The initial temperature profile indicated a maximum temperature of $247.6^{\circ} \mathrm{F}$ at about 5,300 feet. The gradient then reversed to $246.5^{\circ}$ at about 5,600 feet and remained virtually isothermal to the total logging depth of $5,675 \mathrm{ft}$. The zone of maximum temperature correlated with the zone of highest production as indicated by the spinner survey.

After the temperature and spinner logs were completed, a continuous recording pressure/temperature tool was set at 5,200 feet. Temperatures, wellhead pressure and discharge rates were also measured on the flowline by continuous recording digiquartz meters (See Fig. 2.5).

The main objective of the testing program was to predict the transient behavior of well pressures, both at the wellhead and downhole, that would result from flowing at various constant rates and to get a qualitative estimate of the reservoir extent.

The first phase of the testing was comprised of three short term (about $8 \mathrm{hrs.}$ ) constant flow tests at 230 , 460, and $670 \mathrm{gpm}$ with equal time recovery periods after the last two flow periods. A four-day constant flow (620 gpm) test was then performed, followed by a 16 hour recovery period.

The last phase of the well test program consisted of a 16-day constant flow test at $630 \mathrm{gpm}$. This phase served two purposes: (1) to detect any boundary conditions of the reservoir or producing zone which may be 


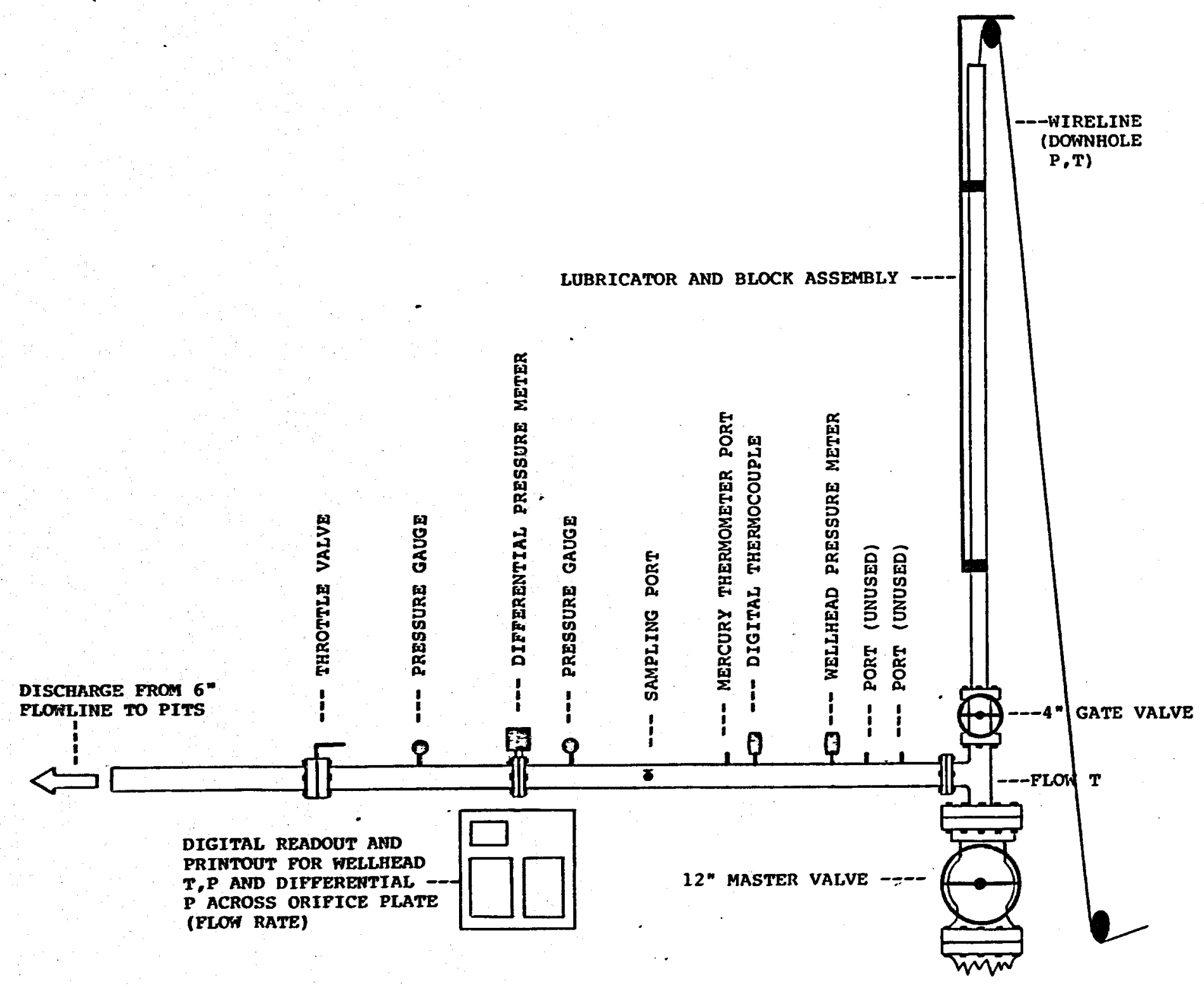

Figure 2-5. Flow Testing Assembly 
encountered as the radius of influence of the well expanded due to the sustained flow, and (2) to observe long term temperature trends both at depth and at the wellhead.

Another important aspect of the testing was the collection of fluid samples to be analyzed for major cations and anions as well as trace elements and the stable isotopes oxygen 18 and deuterium.

Test results project a highly productive well (about 20 gpm/psi capacity) with no immediate boundaries. pressure recovery from testing is very rapid, indicating a highly transmissive producing zone. A minimum reservoir temperature of $251 \cdot F$ was measured at 5,200 feet.

An independent resource analysis* concludes that the reservoir around WEN-1 is $733,000 \mathrm{md}-\mathrm{ft}$, with a reservoir size, based on a fifteen day test, of 193 billion barrels. The reservoir has an estimated radius of investigation of eleven miles.

*"Analysis of Pressure Data from Well WEN-1", Herman Dykstra, Petroleum Engineering Consultant (Concord, California), July 1982. 
A study* was made to evaluate the physical and economic availability of an assured supply of wood fuel over a 30-year plant life. The study was based on the project requiring an assumed 1000 oD tons of fuel daily. The wood to be used as fuel will be limited primarily to residue from forest management operations.

\subsection{Wood Fuel Availability}

The potential fuel resource supply and procurement area examined for the power project is within a 100-mile radius of Susanville which is located about 25 miles west of the proposed project site near Wendel. Within this procurement area, 694 Townships** were identified. Within each township studied, 144 ten-acre sample plots were inventoried for a study total of 924,500 acres within the approximately 15 million acre procurement area. Vegetative classification mapping systems, Landsat data maps, and photointerpretive techniques identified the size and density of the trees and the density of the brush on the sample plots. slope and accessibility of each sample point were determined. Within the procurement area acreage identified and located, projections of total available biomass from those areas were developed. The availability of wood fuel from the gross volume inventory were estimated for a four-decade period, through 2019, by decade. These estimates required developing appropriate cutting regimens and biomass coefficients for publicly and

* Wood Fuel for Power Generation at Wendel, California", 5 vols., Resource Management Services Inc. (Birmingham, Alabama) and Sverarup/Sverdrup Technology, Inc. (Tullahoma, Tenn.). May 1981.

** A township consists of 36 sections of land each comprising 640 acres. 
privately managed lands and applying these to the land classification inventory.

The fuel procurement area was divided by isobars as shown in Figure 3-1. The isobars are based on the number of hauls a truck could make from a point in the procurement area to the project site and return. Thus, a truck hauling from isobar 2 could make two roundtrips to the site in a 15-hour working day.

Harvesting slash from old growth stands will be a substantial source of wood fuel. Abundant volumes of slash can be collected from large sawtimber-sized stands of Jeffrey, ponderosa, and mixed conifer pine types; white, red, and mixed conifer firs; and mountain hemlock. This harvest method not only represents a principal source of wood fuel, but offers a great benefit to loggers, forest managers and landowners by performing slash disposal and reducing the fire hazard.

The majority of acreage in the procurement area is publicly owned, with the U.S. Forest service and the Bureau of Land Management managing approximately 7 million acres or 88 percent of the public lands. Other categories of ownership are shown in Table 3-1.

Table 3-1

LAND OWNERSHIP

Ownership Class

National Forest

BLM

Other Public

Forest Industry

Non-forest Industry

Reserved

Total
Acres

$3,202,200$

$3,786,200$

945,400

634,000

$4,072,100$

$2,043,900$

$14,683,800$
Percent

22

26

6

4

28

14

100 
DAILY ROUNDTRIP ISOBARS FOR

FUEL CHIP DELIVERY BY TRUCK

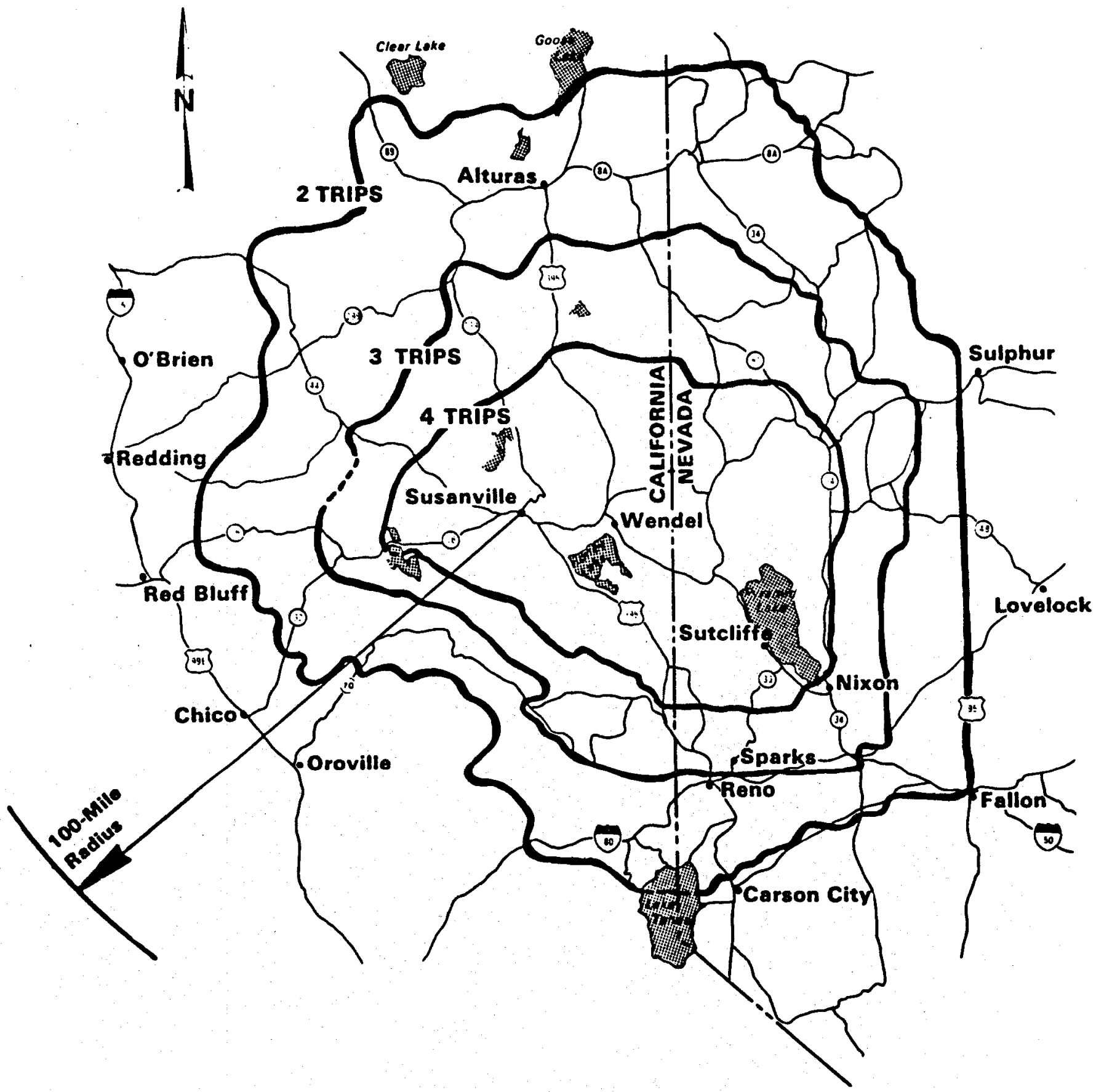

Figure 3-1

Fuel Procurement Area 
The availability of wood fuel for the project is assured in each of the four decades for which projections were made. Overall volumes are so large that the project has substantial flexibility to select fuel sources and harvesting methods that optimize fuel costs. On a decade-by-decade basis, the lowest fuel volumes are projected for the 1980-1989 period, and the need will exist to procure from within the entire procurement area.

The most favorable fuel supply situation occurs in the 1990-1999 decade when the project will be able to rely on fuel in close proximity to the plant site.

In the two decades from 2000-2019, the fuel supply situation becomes progressively less favorable, but still substantially better than in the first decade.

During the 2000 's, the project will have to rely on fuel from larger portions of the procurement area to meet volume requirements. Transportation distances will, however, still remain in a favorable range.

Total volumes of wood fuel projected to be available from all sources within the procurement area for each of the four decades are as follows:*

$\begin{array}{ll}1980-1989 & 1,092,900 \text { OD tons/year } \\ 1990-1999 & 5,151,500 \text { oD tons/year } \\ 2000-2009 & 3,230,900 \text { OD tons/year } \\ 2010-2019 & 2,173,500 \text { OD tons/year }\end{array}$

*These volumes are for residues only, and do not include sources for commercial saw timber, or other round wood uses. 
Thus, the nominal project fuel requirement of 365,000 OD tons/yr. can be obtained easily without entering into competition for home firewood needs.**

The projected surpluses are substantially better than the norms frequently used by the pulp and paper industry to support investment decisions many times the size of the investment level in the Honey Lake Hybrid Power Project.

\subsection{Wood Fuel properties}

Seven general wood fuel supply categories were identified in the susanville procurement area for the hybrid power project. The categories are:

- Lodgepole Pine

- Second growth Ponderosa Pine

- Second growth Fir

- old growth

- Pinyon/Juniper

- Manzanita

- Mill residue

Fuel from each of these seven supply categories has different fuel properties because of species characteristics and different proportions of bark, wood, limbs, and foliage. Properties such as heating value, ash content, and moisture content of each potential fuel source were determined (See Tables 3-2 and 3-3). The results are significant in that fuel values can be considered essentially constant for the boiler design, regardless of supply category. Fuel moisture content ranges from approximately 30 to 50 percent (wet basis) for all supply categories.

** Wood resources for home firewood needs are further protected by the U.S. Forest service policy which accords preferential consideration for domestic firewood use. 
BIOMASS FUEL PROPERTIES FOR

WOOD SPECIES COMMON TO THE

SUSANVILLE PROCUREMENT AREA

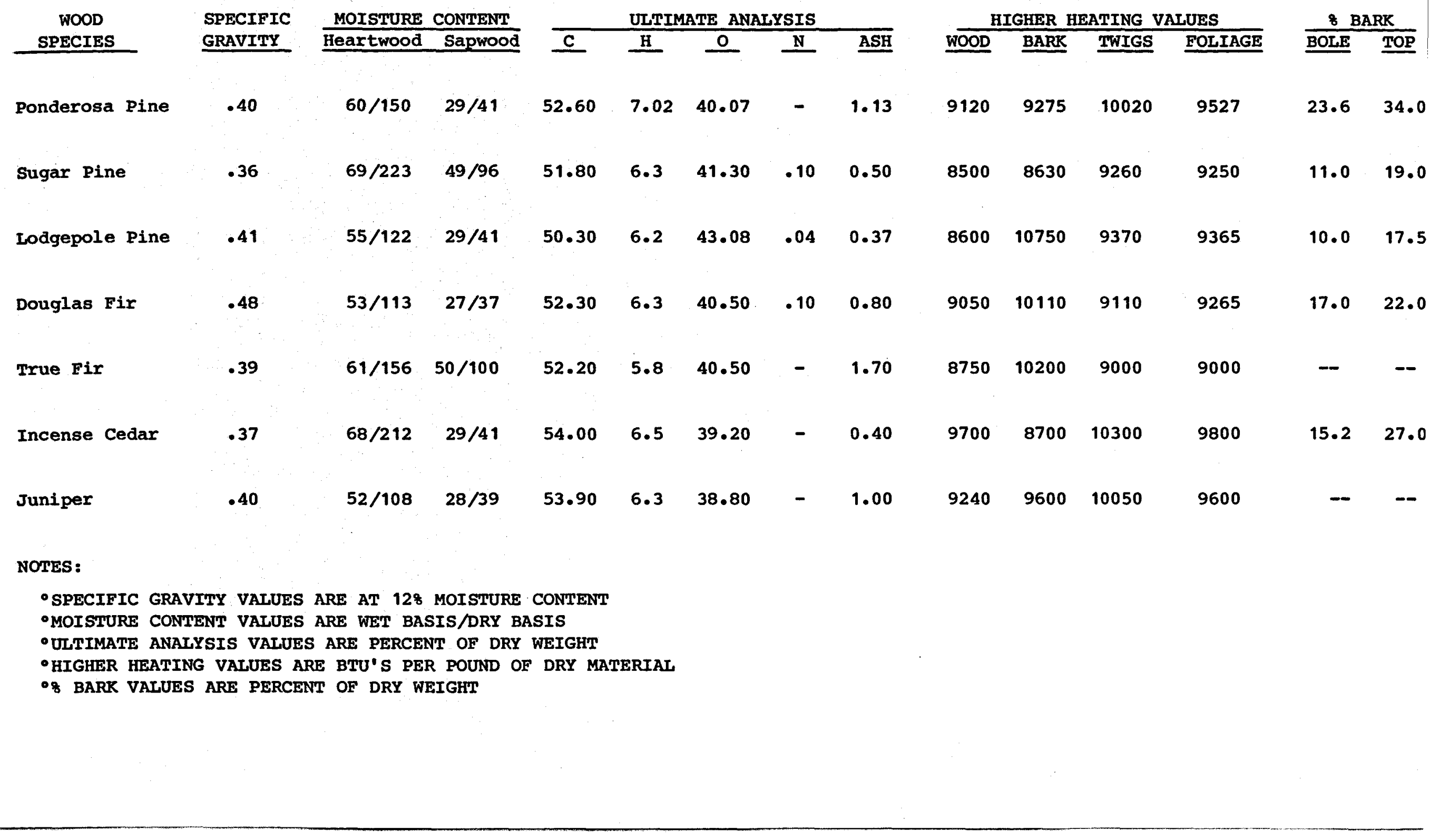


WOOD FUEL HEATING VALUES BY PROCUREMENT AREA SUPPLY CATEGORY

\begin{tabular}{c} 
SUPPLY \\
CATEGORY \\
\hline
\end{tabular}

Lodgepole Pine

Second Growth Ponderosa Pine

Second Growth Fir

\section{FUEL \\ COMPONENTS}

Good Pulp Chip Market

208 saw logs to 7" O.D.,

All bark from 808 of trees;

Bark from 208 of trees $7^{\text {" }} \phi$

$$
\text { to 4" } \phi \text { : }
$$

Top bark from 4"

Needles;

Limbs, branches, and twigs

\section{No Pulp Chip Market}

No sawlogs:

Whole tree processed

Thinnings - No Sawlogs

All bark;

Needles;

Top wood and bark from $4 " \phi$;

Limbs, branches, and twigs

Residue Recovery

Top wood and bark from 4" Needles:

Limbs, branches, and twigs

Residue Recovery
Bark from 7" $\phi$

Needles:

Limbs, branches, and twigs

\begin{tabular}{crrr} 
PERCENT & MOISTURE & \multicolumn{2}{c}{ HEATING VALUES } \\
BARK & OVEN DRY \\
\hline
\end{tabular}

32.0

$41 / 69$

9370

8805

4760

12.5

$47 / 72$

8900

8300

5160

4370

0.60

43.0

$43 / 75$

9300

8750

5300

4540

3.60

34.0

$43 / 75$

9280

8610

5290

4450

2.90

22.0

$39 / 64$

9440

8840

5760

4780

1.50

ASH

CONTENT

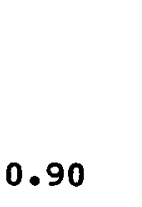

0.90 
Table 3-3 Cont' $d$.

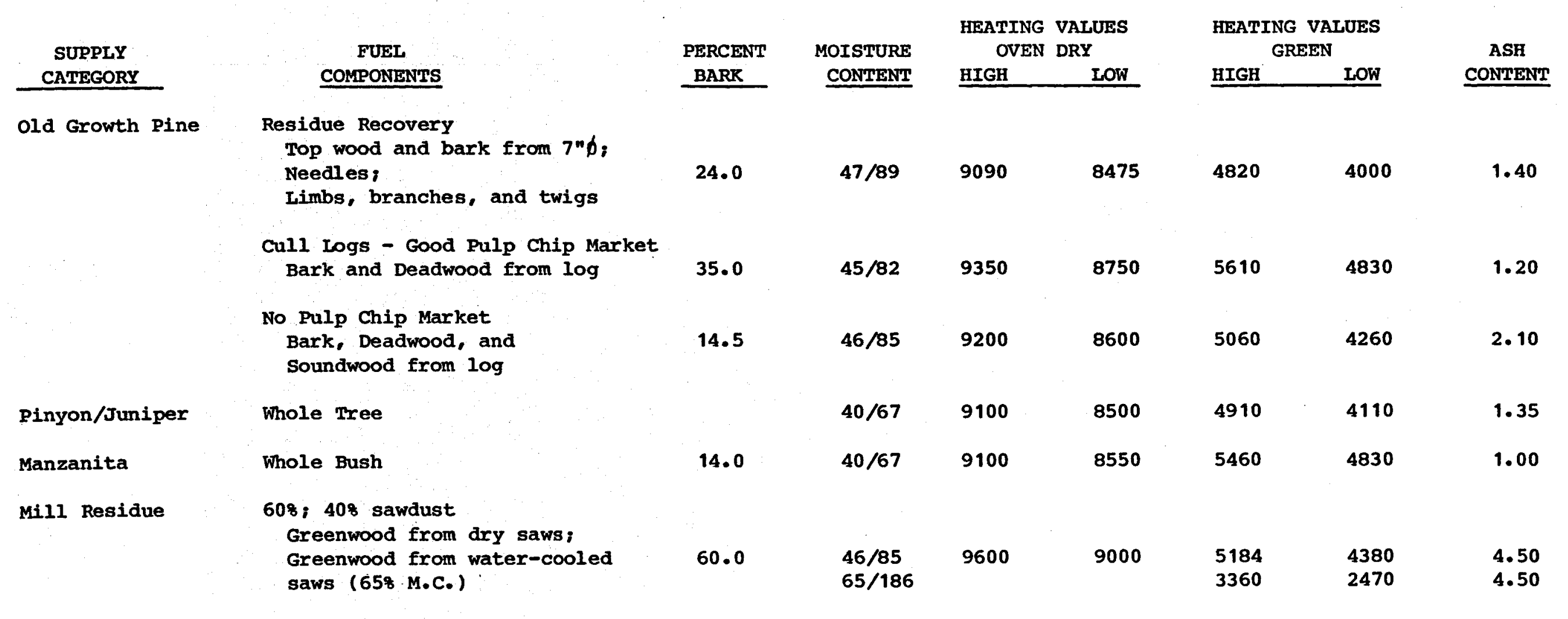

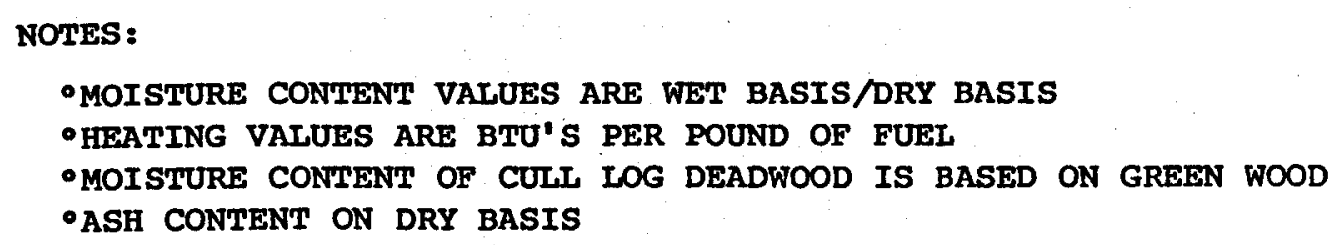


The heating value of the wood fuels relative to moisture content and weather conditions was analyzed.

The water content of green wood is higher in the spring and summer than in the winter but, contrary to popular belief, this seasonal variation is not large. Measured moisture content of species taken at the end of the high rainfall period in the spring suggests that moisture content of freshly harvested trees varies only about \pm 5 percent regardless of weather or time of year.

Fuel-ash content ranges from 0.9 percent to 4.5 percent for the several supply categories. This value is heavily influenced by percentage of bark contained in the fuel.

Soil and rock contamination in forest-based fuels is expected to be substantially lower than contamination found in mill-based bark and green sawdust fuel. One may expect about 1 percent soil and rock contamination; 2.5 percent should be used for design criteria.

Particulate and gaseous emissions from wood combustion, while less troublesome than in other types of plants, need to be considered in selection of plant components. Particulate emissions are a function of fuel properties and combustor design. The fuel properties which have the greatest effect on the unburned carbon particulate are moisture content, wood density, ash content, and fuel particle size. The combustor related variables are firing methods, air distribution, grate heatrelease rate, furnace heat-release rate, residence time, and exhaust gas velocity.

Thus, in general, wood species with higher ash content will have more particulate emission problems. For the 
species under consideration, ponderosa pine (1.31 percent ash), true fir ( 1.7 percent ash) and juniper ( 1.0 percent ash) have the highest weight percent ash. The other species have less than 1 percent ash. High ash content of some species should be considered in the selection of the type of combustor.

Since wood and bark are essentially sulfur-free, low in nitrogen, and require a lower air/fuel ratio for stoichiometric combustion, exhaust gases are essentially free of $\mathrm{NO}_{\mathbf{x}}$ and $\mathrm{SO}_{\mathrm{x}}$. The only appreciable gaseous pollutant from wood combustion is carbon monoxide.

\subsection{Fuel Harvesting Methods}

To ensure practical ability to supply wood fuel to the power plant, the fuel study developed 12 harvesting methods detailing operational functions and economic pro forma results to cover the identified range of conditions within the procurement area. Conditions and considerations used to design harvesting methods included: (a) timber type and stand structure; (b) slope; (c) optimum use value of materials; (d) desired forest management treatment; (e) environmental and ecological requirements; (f) interface with commercial logging operations; and (g) type of logging harvest.

Nine of the harvesting methods consider fuel harvesting from commercial timber types; two treat harvest of noncommercial timber and brush. Procurement of mill residue is also considered. 
All the methods allow economic harvesting and processing of wood fuel into chipped form using existing machinery and equipment.* Fuel from lodgepole pine and old growth on 0 - to 30-percent slopes can be delivered economically to the power plant from within the total procurement area. Fuel from old growth on slopes 31 percent and greater and from pinyon/juniper can be delivered economically from Isobars 3 and 4 (See Fig. 3-1). Ponderosa pine, fir, and brush can only be delivered economically from Isobar 4.

Fuel harvesting from lodgepole pine, old growth, and ponderosa pine will satisfy key objectives related to utilization, forest management goals, and environmental/ecological requirements. Potential damage to residual trees in fir thinnings will allow economic procurement of only a small portion of the available biomass and consequently such fuel harvest will not meet management objectives. Fuel harvest in pinyon/juniper and brush may become practical in the future.

\subsection{Procurement Strategy}

There are adequate volumes of forest-based wood fuel to permit the project to optimize its business opportunity by concentrating procurement on old growth sources. slash from logging in old growth timber stands is abundantly available within the procurement area and is expected to supply over 50 percent of the required fuel. Most of the old growth is located on National

\footnotetext{
*"Economic" is defined for report purposes as fuel delivered to plant inventory in chipped and green form for $\$ 31$ per OD ton in 1980 dollars and value relationships. This cost is in line with major investment decisions in wood-fired energy systems by the pulp and paper industry in 1980 .
} 
Forest lands. The majority of privately owned timberland is second growth which has not reached economic maturity. Under these prevailing circumstances, collection and removal of slash will serve as the principal source of fuel to the power plant and will provide a variety of forest management benefits. About half the slash would be converted into chipped fuel at the collection site; the remainder would be transported by gondola trailers to a fixed-base processing facility at Wendel.

Depending upon the prevailing market price structures in the wood products industry, up to 10 percent of the required plant fuel (perhaps more in the early phase of plant operations) could consist of residues from the 38 sawmills that exist in the procurement area. However, sawmill residue has not been included in the inventory because of expected intense price competition.

The fuel study verifies that implementation of the power plant entails minimal risk from a fuel supply standpoint. Average daily consumption of the basic wood fuel materials and the form in which each would be transported are identified in Table 3-4 below.

Table $3-4$

DAILY CONSUMPTION AND FORM OF WOOD FUEL MATERIALS

Fuel

Material

Lodgepole pine

Consumption

$\frac{(O D \text { tons/day) }}{200}$

Old Growth:

Logging slash

225

Gondola Material

225
Form in which Transported Reduced to fuel chips in the field.

Reduced to fuel chips in the field

Transported as slash, reduced to fuel chips at a fixed-base facility 
Cull Logs

Ponderosa Pine

Fir

Mill Residues

Transported as logs, reduced to fuel chips at a fixed-base facility

175

Reduced to fuel chips in the field

Reduced to fuel chips in the field

100 sawdust

Good highway and railroad networks exist throughout the procurement area to transport forest-based and millbased wood fuel materials to the power plant site at Wendel.

Harvesting operations in the procurement area are highly seasonal. The haryesting season normally runs from about May through November. The plant must have enough fuel in storage to maintain full operation for the months when no fuel is received. Hog fuel should not be stored for longer than 30 days due to possible fire hazards and degradation created by spontaneous heating in the hog fuel storage pile. This 30-day fuel inventory will serve as the fuel supply during the months of active harvesting.

To provide a total of five months storage capacity, a four month supply of whole logs and gondola material is required in addition to the 30 day hog fuel pile. Whole logs are the most effective way to store such a large quantity of wood for a long period of time. Large or irregular logs and gondola material which cannot be reduced in the field would be transported to the plant site for storage and later processing. The whole log and gondola storage area is continually built up during the harvesting season, then during the period without deliveries this fuel is chipped and processed as fuel. An average inventory throughout the year 
should amount to about 105,000 oD tons. A minimum inventory of 30,000 OD tons should be reached at the end of April and a maximum inventory of 180,000 OD tons at the end of November.

\subsection{Wood Fuel Costs}

The cost of wood fuel to the project is estimated for the 1980-1989 decade and is based upon prevailing equipment, fuel; and labor rates in northeastern California during the last half of 1980. Table 3-5 is organized to show the cost of fuel from each source and location in ascending order. In Table 3-6 below, cost estimates are provided for the old growth materials which are expected to provide most of the plant's fuel requirements.

Table 3-5

ESTIMATED COST OF FUEL BY SOURCE AND LOCATION

Source @ slope

Old Growth 0-308

Lodgepole Pine 0-308

old Growth $318+$

Old Growth 0-30\%

Pinyon/Juniper 0-308

Lodgepole Pine 0-308

old Growth $318+$

Second Growth Fir 0-308

Old Growth $0-30 \%$

Pinyon/Juniper $0-30 \%$

Second Growth Ponderosa Pine 0-30\%

Lodgepole Pine $0-30 \%$

Manzanita $0-30 \%$

old Growth $318+$

Second Growth Fir 0-308

Pinyon/Juniper 0-308

Second Growth Ponderosa Pine 0-30\%

Manzanita $0-308$

Second Growth Fir 0-30\%

Second Growth Ponderosa Pine 0-30\%

Manzanita $0-308$
Trips/Day Cost/Ton

$\$ 20.57$

22.50

23.40

24.59

25.86

26.25

27.41

29.22

29.61

29.61

30.62

30.94

31.10

32.43

32.97

34.30

34.37

34.85

37.66

39.06

39.54

\section{Volume $1,0 \overline{00 \text { OD TOn }}$}

29.6

1.9

14.5

76.7

25.1

5.9

46.3

11.8

39.9

129.2

108.7 
Table 3-6

PROJECTED COST OF FUEL

(Taken from Table 3-5)

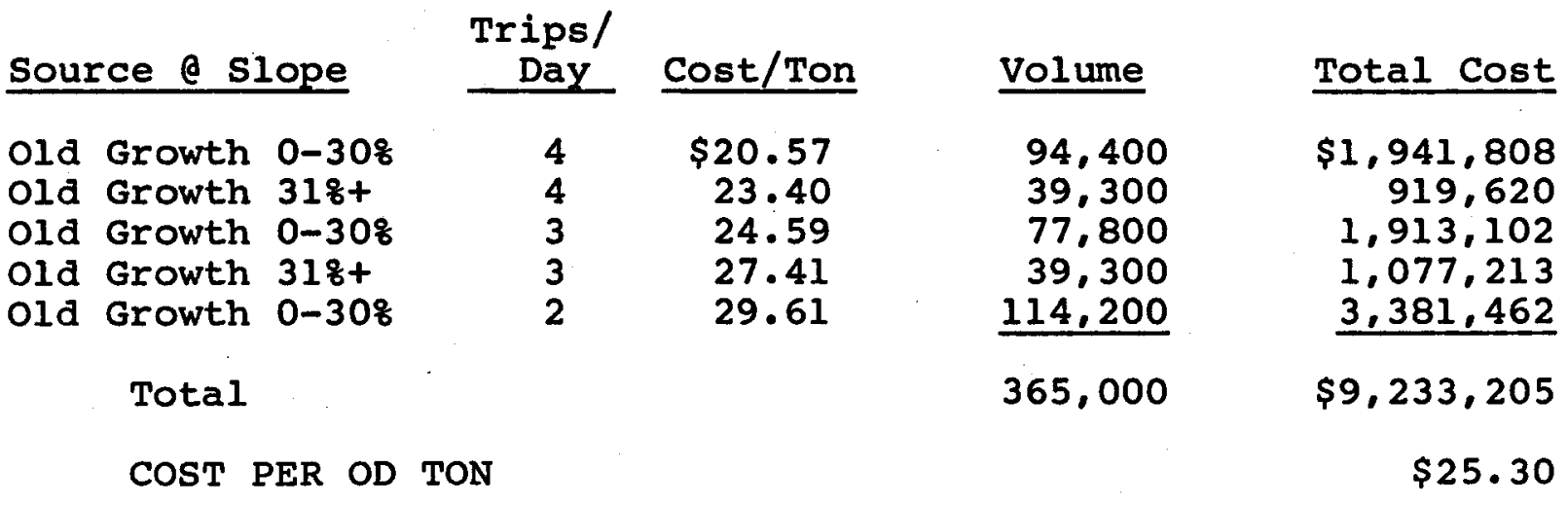

Projection of fuel costs beyond 1989 is conjectural. However, by assuming that cost relationships between equipment, diesel fuel, transportation, labor, etc., remain relatively static and by assuming that fuel values also remain relatively static in comparison to other commodity values for wood-fuel materials, the project can anticipate a substantial reduction in the cost of fuel. In 1980 dollars; fuel costs would amount to $\$ 20.57$ per OD ton in the 1990-1999 decade, $\$ 20.61$ per $O D$ ton in the 2000-2009 decade, and $\$ 21.57$ per OD ton in the 2010-2019 decade.

These improvements are due to the fact that the 1980-1989 decade presents the project with its least favorable procurement circumstances. In subsequent decades, the power plant can be supplied with fuel from smaller working circles than required in the $1980^{\circ} \mathrm{s}$. 


\subsection{Procurement Organization}

It is recommended that the project have its own procurement division to maintain full corporate control of procurement strategy and policies and to carry out all functions important to planning, organization, communication, harvest site selection, and contracting for fuel harvesting. This is necessary to protect the project against: (a) operating losses that would occur if the power plant ran out of wood fuel; and (b) increases in average fuel costs that could occur with third-party procurement in view of variations in fuel cost from $\$ 20.57$ to $\$ 39.54$ per OD ton depending upon source and location.

The procurement division recommended for the project would have a total of 15 employees and an annual operating budget estimated at $\$ 664,000$.

The project should contract the actual harvesting of the fuel and the fuel transportation. Harvesting operations will require employment of approximately 50 persons. Trucking contractors--if they purchased all new equipment to handle the project capacity--would need to invest approximately $\$ 3.2$ million. An estimated 95 new truck driving jobs would be created by implementation of the procurement program.

\subsection{Constraints and Benefits}

There are no identifiable constraints related to acquisition, harvest, and transportation of forestbased wood fuel within the procurement area that would prevent the project from procuring up to 365,000 oD tons of wood fuel per year for the economic life of the proposed power plant. In the decade of tightest supply 
the maximum required fuel is less than one-third the estimated available supply.

There will be a substantial increase in truck traffic through susanville during the projected 170 working days available for harvesting and transportation each year. Apart from an expectation that some might protest increased truck traffic, there would be no restrictions or unusual difficulties imposed against fuel delivery to the power plant, regardless of source location within the procurement area.

The harvesting and transportation of wood fuel to the proposed power plant at Wendel are expected to create over one hundred new jobs in the procurement area. The counties involved experience economically depressed periods and this increase in employment would represent a substantial economic benefit.

The new jobs are expected to generate an estimated $\$ 2.0$ million annual payroll, most of which will be spent in communities near the harvesting and plant sites. A conservative multiplier of three applied to the payroll figure would result in adding approximately $\$ 6.0$ million to the local economies.

The harvesting of slash and dead-and-down trees will help alleviate slash disposal problems of forest land owners and managers. Currently, slash disposal costs average $\$ 125$ per acre. 
Slash disposal is achieved primarily by burning in the woods. Elimination of the need to burn approximately 750,000 tons of green wood annually under incomplete combustion and uncontrolled emission conditions will greatly improve the air quality in the region.

In addition, harvesting of slash will reduce the cost of time suppression and containment, help control insects and disease, and employ more capital in increasing a valuable asset base.

Thinning of precommercial stands will also increase residual stand value. 
The Morrison-Knudsen Company and International Engineering Company jointly completed a preliminary power plant design and economic analysis for the project.* The design provided for the use of geothermal energy to partially dehydrate wood fuel for combustion in a conventional boiler and steam cycle. Geothermal energy would also be used for boiler feedwater heating and combustion air preheating.

The engineering study was undertaken to the detail level where equipment specifications, capital expenditures, and operating costs could be confidently developed. The results of the wood fuel supply study were used to define required wood handling and wood combustion systems. Wood fuel characteristics of 50.8 percent moisture content and 4,502 Btu per pound were used for this preliminary engineering design.

Pending verification of geothermal resource temperature and quality by deep drilling, three temperatures were used for the system design: 225,275 and $340^{\circ} \mathrm{F}$. The three heating and drying applications of the geothermal energy were also evaluated at each temperature.

\subsection{Combustion Optimization}

Cost trade-off studies were performed on the combustion and power generation cycle to facilitate selection of the components, specify design parameters, and evaluate the use of geothermal heat. The combustion options examined included stoker firing, suspension firing,

* Engineering and Economic study Report on the Honey Lake Hybrid Power Plant Project". September 1981. 
fluidized bed combustion, and gas firing. Stoker firing of the wood fuel appeared to offer economic and efficiency advantages not found in the other systems.

\subsection{Plant Capacity Analysis}

Capital, operation, maintenance, and fuel costs were developed for three plant sizes - $-50,35$, and $20 \mathrm{Mw}$. Optimizations were not performed on each plant to determine the operating conditions; however, on the basis of vendor information and historical data, operating conditions were selected for each plant. Generally, the smaller plant sizes have lower pressure and temperature steam delivered to the turbine and require fewer feedwater heaters. The turbine size was selected based on technical information produced by the General Electric Company.

Plant performance or heat rate was predicted for each plant based on the established operating conditions, and the corresponding fuel requirements were determined. Fuel requirements were computed based on auxiliary power requirements, boiler efficiency, cycle heat rate, and fuel heat and moisture content. The effects of geothermal feedwater heating, air heating, and wood drying were included.

Capital costs in 1984 for the 20, 35, and 50 Mw plants were established to be $\$ 49,881,000, \$ 74,481,000$, and $\$ 88,191,000$ respectively excluding interest during construction. The costs were developed to predict relative rates of return on investment, allowing comparisons of the three plant sizes.

The internal rates of return over the 30-year life for 20, 35, and $50 \mathrm{Mw}$ plants are 22.28, 25.48, and 28.08 respectively. 
The 50 Mw plant appears to be the optimum economic size for the Honey Lake Project and was selected for further engineering analysis. However, there are other considerations such as environmental constraints, shorter project schedule and transmission options favoring smaller plants that may improve the viability of the smaller plants.

4.3 Wood Fuel Eandling System

A schematic of the recommended fuel handing system is shown in Figure 4-1. All fuel deliveries are weighed on the incoming truck scale. Chip trucks continue to the trailer dumps where they are emptied into the live bottom receiving hopper. Hog fuel is conveyed to the sizing area where ferrous metals are removed and fuel is sized to less than 2 inches. Fuel is then conveyed to storage.

Economic analysis indicated the fully automatic stackout and reclaim system is preferable for this plant. The additional capital expenditure over a semiautomatic system was shown to yield a 298 rate of return over the life of the plant. The automatic system also maintains first-in/first-out rotation and limiting storage time to 30 days. Since this type of system is not yet in commercial operation, an adequate demonstration of performance and confirmation of costs are necessary before equipment specification is performed in the detalled design phase. If during the detailed design phase, sufficient confidence in performance and price is not evident, the semi-automatic system should be selected.

\subsection{Plant Cycle Optimization}

The power generation cycle consists of all conventional equipment including a turbine receiving steam from the 


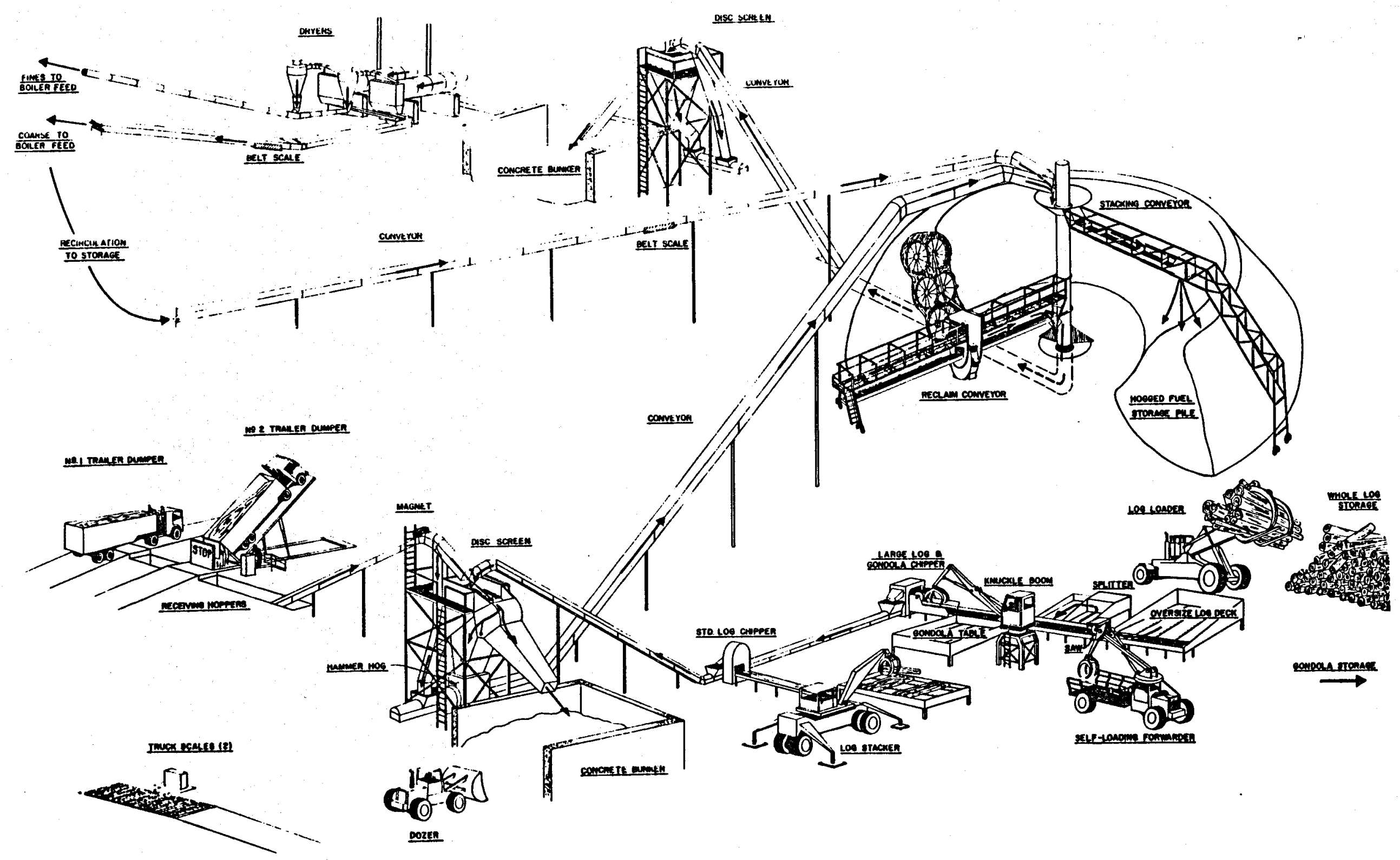

Figure 4-1

Fuel Handling System 
boiler to provide motive force to the generator. The boiler supplies steam to the turbine throttle valves at a temperature and pressure of $950^{\circ} \mathrm{F}$ and 1,450 psig.

Steam exhausted from the turbine is condensed by cooling water from a conventional diked spray type cooling pond. The condensate is pumped through a geothermal heater and steam extraction feedwater heaters before being returned to the boiler to complete the cycle (See Fig. 4-2).

Variations in the thermal cycle cause changes in the cost of equipment and cycle efficiency resulting in changes in the amount of fuel consumed. The variations in the cycle that are analyzed to produce the overall optimum cycle are : (1) turbine throttle (or main steam conditions) and (2) number and arrangement of the regenerative feedwater heaters. The analysis of main steam conditions considers turbine size (bucket length) and reheat and non-reheat variations.

The thermal cycle alternate selected as the optimum delivers the required electrical generation over its operating life at the highest internal rate of return. The rate of return is developed for each of the cycle configurations examined and includes the effect of initial capital cost; fuel cost; and cost for operations and maintenance.

The turbine throttle conditions examined include the following:

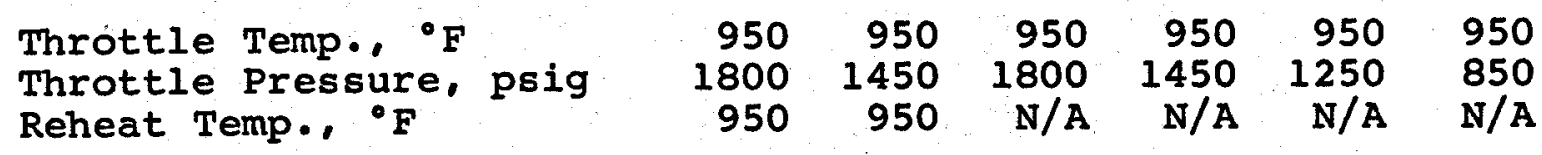




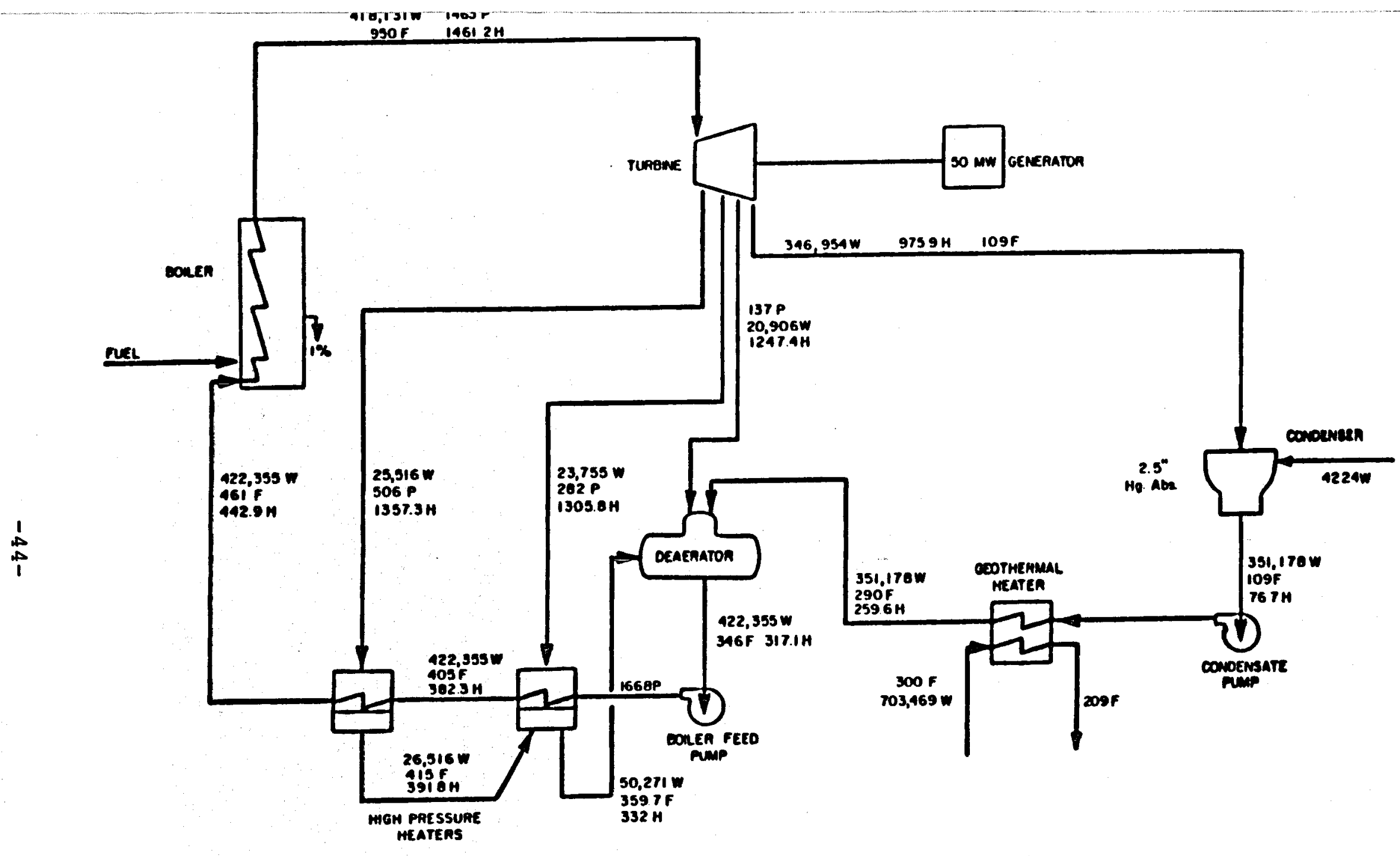

TUEWE KEAT RATE $=8529$ BTU/KWH

n. EnTmaler, otucle

p- mosscine, esia

\author{
Figure 4-2
}

Plant Cycle and Heat Balance Diagram 
The cycle selected has $950^{\circ} \mathrm{F}, 1450$ psig throttle conditions and no reheat.

As feedwater returns from the condenser to the boiler, it travels through heaters supplied with turbine extraction steam for heating the feedwater. Geothermal water is also supplied to a heater for feedwater heating.

Variations in the feedwater heater arrangement and location of the geothermal feedwater heater are analyzed to determine the number of high and low-pressure heaters as well as justification for the geothermal heater. Economic justification for a geothermal heater is analyzed at the three study temperatures. At $225^{\circ} \mathrm{F}$ geothermal water, no geothermal feedwater heater can be economically justified.

\subsection{Wood Fuel Drying}

The moisture content of the wood fuel usually affects the design of the boiler more than any other property. Reduction of fuel moisture content results in a significant increase in boiler efficiency and a decrease in capital cost of the boiler system. Drying wood fuel also reduces boiler particulate emissions. Several types of dryers were examined to determine the most suitable system for the Honey Lake project. The three basic types manufactured in the United States are rotary, tower, and conveyer dryers. A cascade dryer of Swedish design was also studied. In a comparative analysis of the several drying systems their capital; operation and maintenance costs were balanced against the respective performance characteristics in drying wood waste. These characteristics include pollution problems from drying exhaust, increased fines and 
increased fire and explosive hazards. The rotary dryer was selected in this comparative analysis as the optimum system for the Honey Lake project. A schematic of the rotary drying system is shown in Fig. 4-3.

An analysis was then performed to determine the extent to which the wood could be economically dried using each of the three postulated source temperatures. Capital expenditures, fuel savings, and annual operation and maintenance costs vary significantly according to the degree to which the fuel moisture content is lowered. Rates of return were calculated to lower the moisture content from 50.8 percent to, in turn, 45, 30, and 15 percent. The analysis showed that by using $275^{\circ}$ or $340^{\circ} \mathrm{F}$ geothermal water, fuel drying to 45 percent moisture content is the economic optimum. At a geothermal source temperature of $225^{\circ} \mathrm{F}$, no drying is economically feasible. Table 4-1 shows the perfor mance variations with different geothermal temperatures and the range of fuel savings possible with wood arying:

\subsection{Emission Controls}

Combustion products of wood fuel were examined to determine potential air pollutants in the flue gases. Gaseous emissions from the hogged fuel boiler are minimal. Sulfur and nitrogen oxides and carbon monoxide emissions are within environmental guidelines and require no control. However, particulates entrained in the flue gases are substantial. Particulates include unburned carbon and hydrocarbons, unburned wood particles, and sand or dirt carried into the boiler with the fuel. 


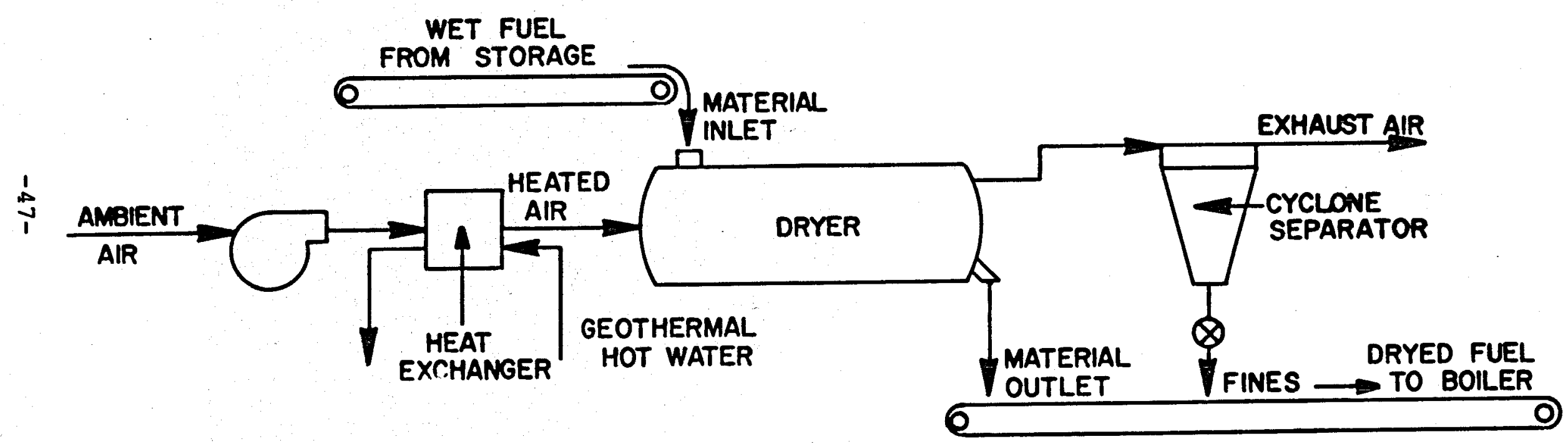

Figure 4-3

ROTARY DRYER 
PERFORMANCE VARIATIONS WITH GEOTHERMAL WOOD DRYING

\begin{tabular}{|c|c|c|c|c|c|c|c|c|c|c|}
\hline Molsture Content of Fuel to Boller, 8 & 50.8 & 45 & 45 & 45 & 30 & 30 & 30 & 15 & 15 & 15 \\
\hline Geothermal Temperature, $F$ & $N_{\bullet} A_{\bullet}$ & 340 & 275 & 225 & 340 & 275 & 225 & 340 & 275 & 225 \\
\hline Air Temperature to dryer, $F$ & $N_{0} A_{0}$ & 305 & 240 & 190 & 305 & 240 & 190 & 305 & 240 & 190 \\
\hline Dryer Exhaust Alr Temperature, $F$ & $N_{0} A_{0}$ & 128 & 119 & 111 & 128 & 119 & 111 & 128 & 119 & 111 \\
\hline \multicolumn{11}{|l|}{ Differential Aux, Power, kw } \\
\hline Boller Fans & Base & -45 & -44 & -42 & -122 & -119 & -114 & -171 & -168 & -162 \\
\hline Dryer Drives & 0 & 15 & 19 & 37 & 56 & 93 & 149 & 130 & 205 & 335 \\
\hline Dryer Fans & 0 & 107 & 157 & 242 & 282 & 414 & 640 & 383 & 564 & 873 \\
\hline Geothermal Pumping & 0 & 45 & 65 & 100 & 117 & 170 & 264 & 160 & 231 & 361 \\
\hline Diff. Total & Base & 122 & 197 & 337 & 333 & 558 & 939 & 502 & 832 & 1408 \\
\hline \multicolumn{11}{|l|}{ Cycle Performance } \\
\hline Diff. Net Plant Heat Rate, Btu/Kwh & Base & -561 & -542 & -508 & -1419 & -1367 & -1280 & -1891 & -1818 & -1692 \\
\hline \multicolumn{11}{|l|}{ Fuel Resulred } \\
\hline Fuel saved, wet tons/yr & Base & 29,264 & 27,591 & 25,390 & 62,276 & 59,608 & 54,967 & 81,037 & 79,634 & 72,057 \\
\hline Fuel saved, O.D. tons/yr & Base & 14,398 & 13,575 & 12,492 & 30,640 & 29,327 & 27,044 & 39,870 & 38,196 & 35,452 \\
\hline
\end{tabular}


Three methods of particulate control were evaluated -electrostatic precipitators (ESP), baghouses, and wet scrubbers. These methods are generally considered to be capable of controlling particulates to within the guidelines specified by government agencies. In each of these methods a multiple cyclone collector preceeds the secondary cleanup equipment. Technical and economic factors were considered in the evaluation.

Fly ash particles emitted from hog fuel boilers is of relatively low resistivity, and therefore tend to act as electrical conductors. As a consequence, they are easily re-entrained in the gas. Electrostatic precipitators were, until recently, uncommon in wood-fired appplications. Current developments in ESP technology have minimized the difficulties associated with collecting this low resistivity ash, and the ESP is now a competitive option for final gas cleanup. An electrostatic precipitator was recommended for this plant.

Although the capital costs for the ESP are slightly higher than for the baghouse or wet scrubber, operating costs show the additional capital expenditure to yield an acceptable rate of return. Other factors contributing to selection of the ESP are that the baghouse is prone to fire hazards when used with a wood boiler and the wet scrubber has high operating costs.

4.7 Ash Handling and Plant Cooling Boiler ash, siftings and air hoppers, and fly ash must be collected for disposal or sale.

Three basic types of ash systems are available -- fully wet systems, dry or pneumatic systems, and damp mecha- 
nical systems. Many variations and combinations of these were considered before five alternates were chosen for detailed analysis. These five alternates are:

1. Hydraulic system to an ash disposal pond

2. Hyaraulic system to dewatering bins

3. Pneumatic system to a dry storage silo

4. Mechanical drag system to dumpsters

5. Combination mechanical bottom ash and hyảraulic fly ash.

Common problems associated with handiing ash from woodfired boilers include fire and explosion hazards, dusting problems, and dewatering of ash. Examination of these problems in conjunction with the relative system costs indicated that Alternative 4, the damp mechanical drag collection system discharging to dumpsters; is the most viable design for the Honey Lake Project.

Three alternative plant cooling systems were studied: (1) the conventional induced-draft mechanical cooling tower: (2) a spray pond system; and (3) a spray pond with a deep water sump to provide thermal storage cooling capability. Relative capital costs and operating costs for each type of cooling system were estimated to provide an objective comparison of alternatives. Results of the operational analysis and economic comparisons suggest that a pond without storage is most suitable for this project.

\subsection{Performance Gains Using Geothermal Energy}

The integration of moderate temperature geothermal heat into a power plant electrical generation process can 
cause substantial reductions in the plant fuel consumed. Basically; heat that is normally supplied from plant fuel is augmented with geothermal heat to cause an increase in power produced in relation to fuel consumed.

Using geothermal heat for heating boiler combustion air causes air at an elevated temperature to enter the boiler, which saves fuel normally required to heat the air. Geothermal heat for wood drying reduces the moisture content of the wood by evaporating and discharging the moisture before the wood enters the boiler. Boiler efficiency is improved and fuel comsumption reduced. Plant performance and fuel comsumption were predicted for each of these uses for each of the three geothermal temperatures.

The combined analyses indicate that heating feedwater using geothermal water at $275^{\circ} \mathrm{F}$ saves up to 4 percent of the fuel required when no geothermal heat is utilized. Similarly, about 6 percent fuel savings is realized when boiler combustion air is preheated with geothermal energy. Geothermal heat theoretically, can be used to dry the wood fuel to practically any degree of moisture content desired regardless of geothermal water temperature. Using $275^{\circ} \mathrm{F}$ water to dry the wood to 45 percent moisture causes a corresponding 5 percent savings in wood. If all three methods of incorporating geothermal heat into the plant are utilized, a total fuel savings of about 14 percent is produced.

Table 4-2 shows the effect of using geothermal heat in economically feasible applications. At $225^{\circ} \mathrm{F}$, no feedwater heating or wood drying is justified. 
Table 4-2

\section{PERFORMANCE GAINS FROM ECONOMICALLY FEASIBLE}

GEOTHERMAL APPLICATIONS

$\begin{array}{lrrr}\text { Geothermal Temp., }{ }^{\circ} \mathrm{F} & 225 & 275 & 340 \\ \text { Feedwater Heating } & \text { No } & \text { Yes } & \text { Yes } \\ \text { Combustion Air Heating } & \text { Yes } & \text { Yes } & \text { Yes } \\ \text { Wood Fuel Drying } & \text { No } & \text { Yes } & \text { Yes } \\ \text { Fuel Saved, Wet Ton/Yr. } & 22,997 & 76,917 & 101,973 \\ \text { \& Fuel Saved } & 4.3 & 14.3 & 19.0\end{array}$

4.9 Economic Analysis

After all the plant systems were defined and preliminary specifications prepared, preliminary drawings were developed including piping and instrument diagrams, site plan, electrical one-line diagram and general arrangement drawings. These drawings, together with a detailed equipment list, were used as a basis for developing capital cost estimates. The plant design at the $275^{\circ} \mathrm{F}$ temperature is taken as the base case upon which detailed estimates were made. Total investment for a plant using $275^{\circ} \mathrm{F}$ geothermal water is estimated to be $\$ 87,544,000$ (excluding construction interest) at the January 1985 commercial operation date, resulting in a unit cost of $\$ 1,750$ per $\mathrm{KW}$.

Table 4-3 shows the plant investment ( 1981 basis) for each temperature as well as the basis for determining wood cost, geothermal heat, operating and maintenance costs, and revenue from power sold. 
Table 4-3

PLANT INVESTMENT AND COSTS

Geothermal Temp.; ${ }^{\circ} \mathrm{F}$.

225

275

340

Costs, $\$ 1,000$

Direct Investment

Power Plant
Mobile Equipment

Subtotal

Geothermal Well system

Construction Gen. Exp.; Overhead, Fee

Land

Total Direct

\begin{tabular}{r}
44,164 \\
705 \\
\hline 44,869 \\
1,528
\end{tabular}

44,243

43,909

$\frac{705}{44,948}$

44,614

2,461

2,461

8,230

8,409

8,350

$\frac{80}{54,707}$

55,898

$\frac{80}{55,505}$

Misc. Investment

Wood Inventory

Sales Tax

Environ. Permitting

Engineering \& Fee

2,900

1,670

637

General \& Administrative

5,165

3,073

Contingency

Total Misc.

$\frac{3,915}{17,360}$

2,596

1,706

2,456

637

1,694

637

5,231

5,231

3,138

3,117

$\frac{3,997}{17,305}$

$\frac{3,971}{17,106}$

Total Investment

72,067

73,203

72,611

\section{Plant Operations}

$\begin{array}{lrrr}\text { Operating \& Maint.; \$1000 } & 1,377 & 1,407 & 1,397 \\ \text { Wood Fuel Required; ODT/YR } & 253,000 & 226,500 & 214,200 \\ \text { Power from Geothermal Heat } & 2,016 & 6,546 & 8,909 \\ \text { KW } & 15,0111 & 48,7415 & 66.3364 \\ \quad \text { Gigawatts Hrs/Yr } & & & \\ \text { Net Power Sold } & 45,825 & 45,540 & 45,658 \\ \text { KW } & 341,2129 & 339.0908 & 339.9695 \\ \text { Gigawatts Hrs/Yr } & & & \end{array}$

Project rates of return; according to geothermal source temperature, interest rates, and project financial structure are shown in Table 4-4. 
Table 4-4

RATES OF RETURN

Geothermal Temp., 'F

Rate of Return on Equity Portion*

88 interest

118 interest

148 interest

Rate of Return Assuming

1008 equity (Internal)

First Year Cost of Produced Power (Mills/KwH)
225

275

340

42.8

42.3

43.5

39.3

38.8

39.9

35.8

35.3

36.3

22.4

22.2

22.5

58.6

57.8

56.6 
5. 0 ENVIRONMENTAL ISSUES ASSESSMENT

A report has been prepared which identifies potential environmental, health, and socio-economic issues pertinent to the project.* The report addresses permitting and Iicensing requirements at the respective government levels, describes additional data requirements necessary for processing of required applications and documents, and provides an identification of sensitive environmental issues in the proposed project area. An extensive annotated bibliography of relevant ilterature with appropriate statutes and regulations is included. The report also presents a budget and schedule for accomplishing required data acquisition and permit processing activities prior to construction.

The report concludes that while certain mitigating measures must be undertaken in the final engineering design phase of the project, there are no outstanding environmental issues that would preclude project construction and operation.

\subsection{State Certification}

Any thermal power plant, as the Honey Lake plant will probably be defined, having a generating capacity of 50 megawatts or greater comes under the jurisdiction of the California Energy Commission (CEC) and must be certified by the Commission prior to beginning of construction. If the generating plant is less than 50 MW, the projects compliance with the California Environmental Quality Act can be certifled by a designated "lead agency".

*Identification of Environmental Issues: Hybrid Wood-Geothermal power Plant, Wenael-Amedee KGRA, Lassen County, California", 2 volumes, Gennis and Assoclates, Sacramento (August, 1981). 
The Public Utility Regulatory Policies Act (1978) provides that small power producers are exempt from state and federal utility regulations as of March 20, 1981. Small power projects are those defined as generating less than $80 \mathrm{Mw}(e)$ and like the Honey Lake project, employing renewable resources, including geothermal energy and biomass, as a primary fuel.

\subsection{Air Quality Maintenance}

Air pollutants can be classified as either gaseous or particulate pollutants. Gaseous pollutants produced by wood combustion include carbon monoxide ( $\mathrm{CO}$, oxides of nitrogen (NOX) and unburned hydrocarbon gases. Particulate pollutants produced include flyash, unburned carbon particles, condensed droplets of liquid hydrocarbons and metallic salts. Emissions of gaseous pollutants are minimal for well operated units fired with wood. The fuel is inherently low in sulfur, and the high moisture content helps to maintain temperatures in the boller to a low enough range that formation of oxides of nitrogen is not a major problem. Emissions of particulates, however, can be substantial. Multiple cyclone collector and electrostatic precipitator control systems must be installed to control these pollutants.

Although the U.S.E.P.A. designates the Northeast Plateau Air Basin as an attainment area which merits special consideration, susanville and the Honey Lake Area to the east are quite susceptible to frequent air stagnation and accumulation of air pollutants due to reduced ventilation. It will therefore be necessary to establish a substantial baseline air quality and meteorological monitoring program to provide information necessary for a complete air quality modeling 
study. This modeling study will determine probable air quality effects of the project and thereby define areas requiring additional technical and design work to meet air quality standards.

\subsection{Other Environmental Issues}

- Land Use, Vegetation, and Wildlife.

The proposed project area contains six vegetative associations: Annual grasses, sagebrush, greasewood, saltgrass, salt desert shrubs, and alfalfa cropland. No rare or endangered plant or animal species are resident in the project area, although bald eagles have been seen transiting the area. Land clearing, drilling, and plant construction activities will destroy native plant communities in those sitespecific activities. Once the project site is selected, specific studies on potential environmental disruption and mitigation measures will be undertaken. Existing land use is predominantly agricultural and grazing, with little or no development.

\section{- Geotechnical}

No data exists concerning the engineering characteristics of site soils, which are predominately sandy loams and sand. Engineering design must take into account possible settling problems.

Extensive groundwater storage capacity exists in the general project area. While the estimated plant water demand is only about 1300 acre feet, groundwater levels may diminish slightly if an overdraft condition already exists. Final engineering design should take into account the possibility of using the geothermal fluids for cooling and as many auxiliary purposes as possible. To the extent possible, 
geothermal fluids should be used for cooling and related plant water uses so as to avoid reliance on fresh water sources currently being used for irrigation and wildlife purposes.

Subsidence is not likely to be of great concern, since the geothermal fluid is being produced entirely from a fractured zone in granitic basement below 5,000 feet.

According to existing seismic data, the plant can be designed to withstand the expected range of natural seismic events.

- Waste Disposal

The geothermal fluid, alone or with other liquid waste streams may be disposed of by injection or surface discharge, depending on the final determination of chemical constituents and review by state regulatory authorities. The potential does exist for beneficial use of the geothermal fluid through discharge to one or both of the wildfowl management areas located on the north side of Honey Lake. The high ground water table will probably preclude use of percolation or septic systems for domestic wastewater. Lined evaporation ponds could possibly be used for some waste water disposal.

Wood ash will be the principal solid waste, resulting in the need to handle up to 20 tons per day. Final disposition of the ash would follow extensive combustion testing with the major concern being its salt content and the resultant threat of groundwater pollution. Land-fill burial or commercial reuse are the major disposal options. In some instances wood 
ash can be used as a fertilizer, either directly for its potassium content or mixed with compost. The commercial potential for this or related uses needs to be investigated.

- Cultural Resources

A large number of archaeological resources exist in the Honey Lake area. A historic property (the Eagle Lake Ditch) also transits the general project area. The specific locations of cultural resources with respect to possible plant sites needs to be examined and any concerns of native Americans, particularly the locales of any ceremonial/religious sites, addressed. Archaeological field studies were undertaken for the drilling sites and access roads discussed in section 2.0 .

- Socio-Economics

The employment and financial benefits of the project to Lassen County will be substantial. The present unemployment rate in susanville is about 25 percent. Jobs created by project construction, plant operation, and wood procurement activities will add a badly needed employment dimension to the predominately government and lumber based economy of the area. (See Table 5-1). The property tax base would be aided significantly by an estimated annual assessment of $\$ 650,000$. 
Table 5-1

ESTIMATED DIRECT EMPLOYMENT

\begin{tabular}{|c|c|c|}
\hline Activity & Approximate Duration & $\begin{array}{l}\text { Estimated } \\
\text { People } \\
\text { Employed }\end{array}$ \\
\hline $\begin{array}{l}\text { Well Drilling (One to } \\
\text { three production wells } \\
\text { and possibly one rein- } \\
\text { jection well will be } \\
\text { required) }\end{array}$ & 2 months per well & $\begin{array}{l}20 \text { men per } \\
\text { rig }\end{array}$ \\
\hline Power Plant construction & $2-1 / 2$ Years & $\begin{array}{l}10 \text { to } 80 \\
\text { (average } \\
\text { about } 40 \text { ) }\end{array}$ \\
\hline Power Plant Operation & Year-round & 20 to 40 \\
\hline Wood Procurement & Year-round & 15 \\
\hline Wood Harvesting & 7 months/year & 50 \\
\hline Wood Hauling & 7 months/year & 95 \\
\hline
\end{tabular}

Potentially adverse effects of the project include increased truck traffic through susanville (although it is not expected to affect traffic flow through the town), and accelerated deterioration of some roads, particularly Wendel Road, from the increased heavy traffic.

A major area of public concern is that the project will compete with the local population for home firewood. While all evidence, including the wood fuel resource study, suggests that this will not be the case, this is nevertheless an issue that will require constant attention and public education by the Forest Service and other forest land managers. 
5.4 Design of Mitigation Measures

The Honey Lake Project will comply with the letter and spirit of existing environmental regulations and statutes by using the best available technology that is commercially feasible to reduce potentially adverse effects such as using two stages of air pollution control equipment if necessary to minimize particulate emissions. In many instances project design features will specifically circumvent the causes of environmental impacts. These design features include predrying of the wood fuel to ensure more complete combustion, using fuel having very low gaseous pollutants, minimal reliance on water from the shallow aquifer, reducing truck traffic by adding trailer units, returning plant ashes as fertilizer for agriculture or forest use, and harvesting forest slash and dead/down trees to reduce fire hazards and diseases to enhance future forest growth and yields. 


\subsection{IMPLEMENTATION ACTIONS}

Significant conclusions reached in the respective study areas were summarized in section 1.0. The phase of the project represented by this completed feasibility study has defined a number of issues and activities that need to be addressed before the participants can intelligently commit to plant construction, among which are the following:

(1) Planning needs to be undertaken for further drilling operations to develop the well field, including the provision for deep injection if it appears, after discussions with state regulatory authorities, that such fluid disposal means will be required.

(2) Reservoir engineering should begin as early as is practical, commencing with the existing deep well and including subsequent wells as they are drilled, the purpose of which is to project the longevity of the geothermal resource relative to plant requirements.

(3) Transmission and intertie alternatives need to be explored and resolved to the satisfaction of the participants.

(4) Financial planning for the project, both long term debt and equity funding should be identified to permit final cost and rate of return analysis.

(5) Plans should be formulated for undertaking the necessary environmental baseline studies and for ensuring timely compliance with all permit requirements. 
(6) A long term power purchase agreement(s) need to be negotiated.

(7) Final engineering design and cost analysis should be provided, with the plant power cycle and plant capacity based on the proven geothermal resource temperature. Selection of optimum systems for handling of waste stream discharges and design of measures to minimize adverse environmental effects should be undertaken.

(8) The most cost effective business arrangement for supplying wood fuel should be determined. This determination should identify actual delivered fuel costs to assist in final project rate of return analysis. 
7.0 RELATED STUDIES

The plant engineering, wood resource, and environmental studies described in preceding sections were being completed at about the time the deep drilling commenced on exploratory well WEN-1. The temperature in that highly productive well, as discussed in section 2.0 , is about midway between the low and middle temperatures used for design bases in the IECO/MK engineering feasibility study. Subsequent to completion of the feasibility study, Geoproducts Corporation undertook related engineering and cost evaluations based on the known resource temperature from $W E N-1$, and assumed that similar temperatures would probably be encountered in subsequent deep development wells on the Honey Lake prospect.

7.1 Combined Cycle Plant Design

At a wellhead temperature of $245^{\circ}-255^{\circ} \mathrm{F}$, as is the case with WEN-1, it appears that better economic use can be made of the geothermal energy by employing it in a working fluid binary power cycle which parallels and is augmented by a conventional steam cycle obtained by burning wood wastes provided by local suppliers at a moisture content of about 45 percent. This alternate plant cycle was examined by Morrison-Knudsen and International Engineering Company in a recent report which confirmed the technical and economic feasibility of the combined cycle project.*

A low temperature power generation loop will use a binary working fluid in a Rankine cycle which includes

*"Hybrid-Combined Cycle Power Plant Using Geothermal and Wood Fuel Resources", December 1981. 
two stages of binary vaporizers, a gas expansion turbine for driving a 13,540 kilowatt gross capacity generator, a water cooled binary condenser and condensate feed pump for pressurizing and returning fluid to the two vaporizers (See Figure 7-1). A heat recovery heat exchanger within the binary loop may be added (but is not shown) depending upon the superheat in the binary exhaust. The first stage binary vaporizer is heated by $250^{\circ} \mathrm{F}$ entering geothermal fluids. The second stage binary vaporizer is heated by the entering $335 \cdot \mathrm{F}$ superheated exhaust steam which is condensed at a saturated condition of 57.5 psia and $290^{\circ} \mathrm{F}$. The binary condenser is cooled by water circulated from a cooling tower. The average annual temperature of air available for the cooling tower at the Honey Lake site is $49 \cdot \mathrm{F}$.

Allowance for in plant uses reduces the net binary cycle output to $11,330 \mathrm{~kW}$. The binary cycle net efficiency is reported by the manufacturer to be 14.5 percent for these operating conditions.

Wood chips are available from a local supplier near the project site at 458 moisture content and at a heat of combustion of $5000 \mathrm{BTU} /$ pound on a wet basis. The cost of this fuel is expected to be $\$ 20.57$ per oven dry (O.D.) ton delivered to the site year round at an approximate particle size of $2 \times 2 \times 1$ inch. This particle size is too large for economical heat drying of the chips. Heat drying of the fuel was considered and rejected because of the additional equipment needed such as a hammermill, additional chip screens, dryers with air pollution controls, and material handling subsystems for recycling the fuel. 


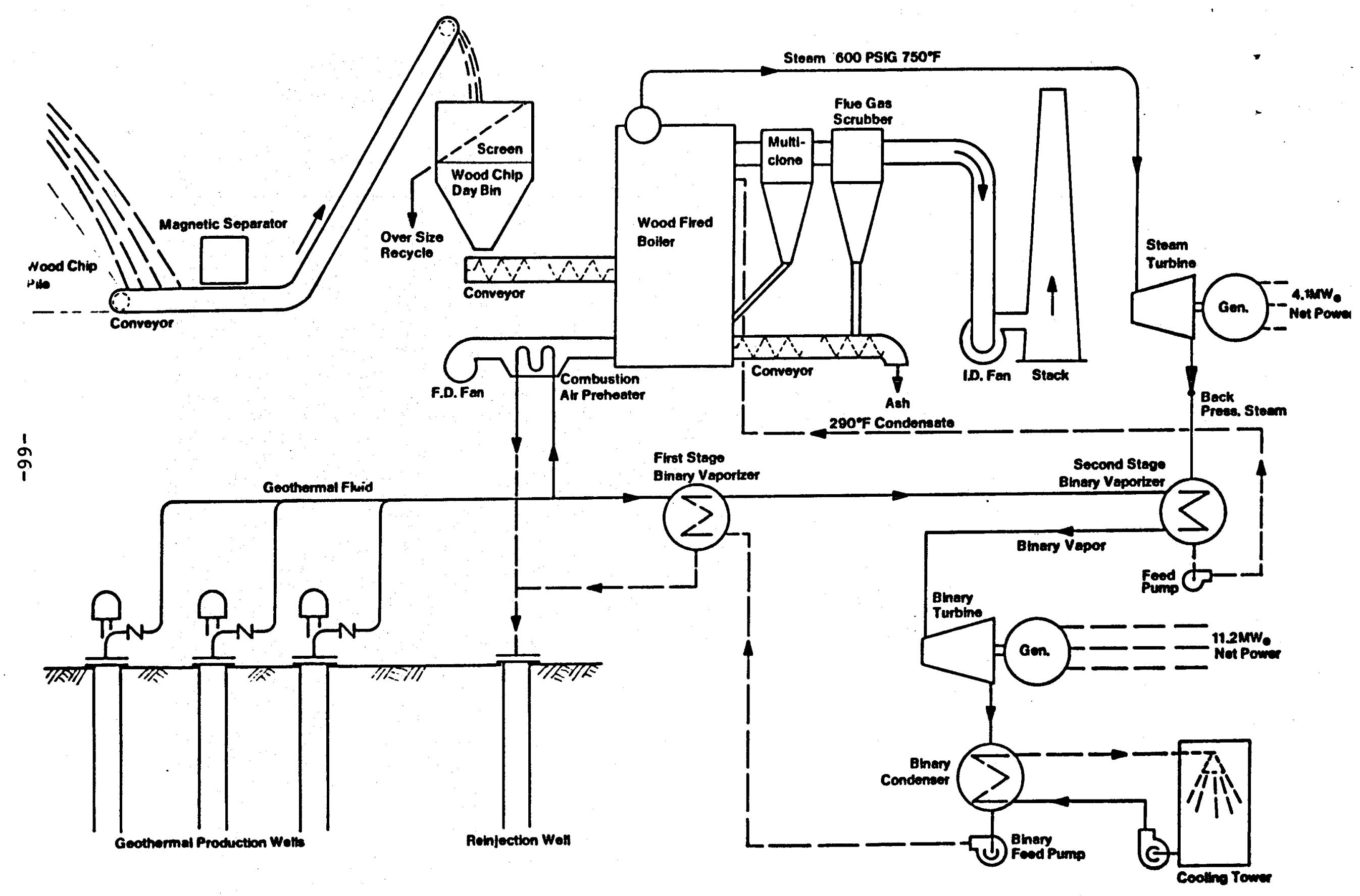

Figure 7-1

Combined Cycle Plant Schematic Diagram 
The steam turbine generator selected produces $4512 \mathrm{KW}$ (gross) and 4164 (net). Wood chips from the day storage bin are fed to a conventional wood-fired traveling grate or pin-hole grate steam boiler having a basic efficiency of 68 percent with 45 percent moisture fuel. Wood gasifiers with waste heat boilers were investigated and rejected because efficiencies offered were only 60 to 62 percent and capital costs were higher. The combustion air will be preheated by geothermal fluids in a heat exchanger which will aid in combustion of fuel on the boiler grate.

Steam conditions of 600 PSIG and $750^{\circ} \mathrm{F}$ were selected to match the operating conditions for the $4512 \mathrm{KW}$ gross capacity back-pressure steam turbine generator. At 42.5 PSIG back pressure a Terry JS back pressure unit has an approximate turbine efficiency of 76 percent. Steam exhaust from the turbine has superheat which is removed along with the heat of condensation in the second stage heat exchanger which vaporizes and heats the binary fluid prior to its entrance to the binary expansion turbine. Condensate from the steam leaves the heat exchanger at $290^{\circ} \mathrm{F}$ and is then pumped via the deaerator (which is not shown on the schematic) to the boiler economizer unit where the feedwater is heated to near saturated temperature of $488^{\circ} \mathrm{F}$ at 600 PSIG.

Capital costs for the combined cycle plant and geothermal fluid supply system are estimated at $\$ 27.5$ million and annual operating costs (excluding interest, depreciation, or amortization) including energy costs about $\$ 3.4$ million. 
A smaller hybrid combined cycle plant at the Wendel location appears to offer a number of advantages that may temper the usual conclusion that larger power plants are more economic. These advantages include the following:

1. A plant capacity of 20 MW or less could be accomodated more readily within the existing electrical transmission system.

2. A smaller plant could be on line sooner, have reduced interest and lower field labor costs during construction because of shorter delivery and reduced field work to install skid-mounted plant equipment.

3. Wood fuel requirements are reduced by 40 percent allowing a more diversified supply base, reducing traffic and travel distances for supply trucks.

4. The reduced procurement radius will lead to a direct reduction in the cost of fuel.

\subsection{Comparative Cost Analysis}

The advantages of a smaller combined cycle project noted above appear to be strengthened by comparative analyses of installed costs, operational costs, and cost of power.

The 50 MW plant project is about three times more costly than the 18.7 MW combined cycle plant $(\$ 87.5$ million to $\$ 27.5$ million, each excluding construction period interest). Installed per kilowatt costs in 1985 
are $\$ 1750$ and $\$ 1473$, respectively. Interest during construction is also accordingly greater for the larger project, $\$ 13.1$ million versus $\$ 3.74$ million for the smaller facility.*

Comparative first year (January 1985) operational expenses are shown in Table 7-1.** The cost advantage of the smaller combined cycle project is particularly apparent in the savings on wood fuel, even though the smaller project appears to be more costly in terms of operation, maintenance and overhead.

Thus from an overall perspective, given the temperature in the first exploration/production well drilled at Wendel, undertaking the smaller combined cycle project appears to offer a number of important technical and economic advantages including getting the project on line sooner at reduced overall costs and, as illustrated in Table $7-1$, at reduced power costs.

*Assuming 7 quarters of construction with interest at 17.58 annualiy and cost escalation at 78 .

**The operational expenses are based on complete project financing for 20 years at 118 cost of capital, 20 year straight line depreciation, and a 108 salvage value. 
Table 7-1

FIRST YEAR OPERATING EXPENSES

AND COST OF POWER(I)

Expense

50 MWe

(\$000's) Mills

18.7 MWe

Operation \&

Maintenance

$1,986.00$

5.86

312.81

2.75

Labor

0

0 *

649.96

5.71

Wood Fuel

$7,709.00$

22.74

$1,328.44$

11.66

Interest

$11,073.00$

32.66

$3,440.90$

30.21

Geothermal Heat

$$
487.00
$$

1.44

507.15

4.45

Insurance

191.00

.56

62.56

.55

Property Tax

875.00

2.58

312.81

2.75

Overhead

$\frac{0}{22321.00} \frac{0 *}{65.84}$

218.97

1.92

TOTAL CASH EXPENSES

$22,321.00$

65.84

$6,833.60$

60.00

Depreciation

$4,529.88$

13.36

$1,407.64$

12.36

TOTAL COST OF POWER

$26,850.88$

79.18

$8,241.24$

72.36

(1) .85 capacity factor

* Incluaded in Operations and Maintenance 